\title{
The Varying Impact of Land Use and Climate in Holocene Landscape Dynamics in the Mezzogiorno
}

\author{
By Peter Wigand \\ Myles McCallum ${ }^{\dagger}$
}

The relative relationship of Holocene climate change, human cultures, and landscape evolution is unclear. However, palaeoecological and archaeological records, suggest that both have played an important role, acting in combination to varying degrees through time, to affect landscape dynamics. The country straddling the Puglia and Basilicata border region in southern Italy (the Mezzogiorno) is a landscape particularly sensitive to erosional processes, and provides an ideal area where these relationships can be studied. In addition, the affects of climate change in this area are magnified by poor land use practices that are being applied to an unstable, and easily erodible, surface geology. Moreover recent palaeoecological and archaeological research in this hilly country is also providing vital information regarding the role of climate and people in landscape dynamics. Four summers of preliminary research with a team consisting of a paleoecologist/geomorphologist, archaeologist, and a dendroclimatologist, has begun reconstruction of a full Holocene climate history from the records of alluvial erosion/deposition, spring discharge, and soil formation. These will aid in determing how climate, and human demography in the Puglia/Basilicata region relate to landscape dynamics. Archaeological surveys have already mapped the varying spatial distribution of cultural materials, providing an assessment of where people lived, population sizes, and their activities during the Holocene. Numerous dated erosion/deposition sequences in alluvium and valley terrace exposures along the Basentello/Bradano River valley detail the regional record of erosional cycles. Dated spring discharge events are beginning to record groundwater recharge linked either to climate, or to deforestation. In addition, dated soil formation episodes are evidence episodes of ground surface stability. A macrophysical climate model of local past effective precipitation is being used to reconstruct cycles of past erosion. These understandings are being used to predict future outcomes of global climate change.

Keywords: Landscape dynamics, Late Quaternary, Land use, Mezzogiorno, Palaeoclimate, Palaeo-erosion Modeling.

\section{Introduction}

Detailed knowledge of human farming activity and of landscape dynamics in regions marginal to the area of central Roman hegemony during the late Republic and Early Imperial periods is limited. This is

\footnotetext{
* Graduate Faculty, University of Nevada, Reno, and California State University, Bakersfield, and Affiliate Associate Research Professor, Desert Research Institute, Reno, USA.

${ }^{\dagger}$ Associate Professor, Saint Mary's University, Halifax, Nova Scotia, Canada.
} 
especially true in the regions, such southern Italy, that had just come under Roman rule and where consolidation was ongoing (Figure 1). Roman historical accounts in these areas are rare, or non-existent, and they rarely discuss human activity upon the land, and never provide information about the landscapes themselves. Therefore, excavations in these areas are conducted in a near vacuum, where the information needed for a robust understanding of these cultures is usually absent or fragmentary at best.

San Felice, a villa of the early Imperial period of the Roman Empire, has been extensively excavated (Small 2003, Small and Small 2005, Favia et al. 2005, Small 2006, Small and Small 2007) (Figure 1), but many questions remain unresolved (McCallum and vanderLeest 2014, McCallum et al. 2011, McCallum 2015). We have hints of what was grown, and raised by the people who lived there, but we know little of what part of the landscape was utilized, or how extensively the landscape was impacted.

Figure 1. View to the Northwest over the San Felice Villa Site (Cluster of People at Lower Left) Towards Lago Di Serra Del Corvo. On the Left Center Horizon Is The Dim Profile Of Monte Vulture. Inserts are of the San Felice Villa Excavations. The Site Lies Just $10.7 \mathrm{Km}$ West Gravina in Puglia

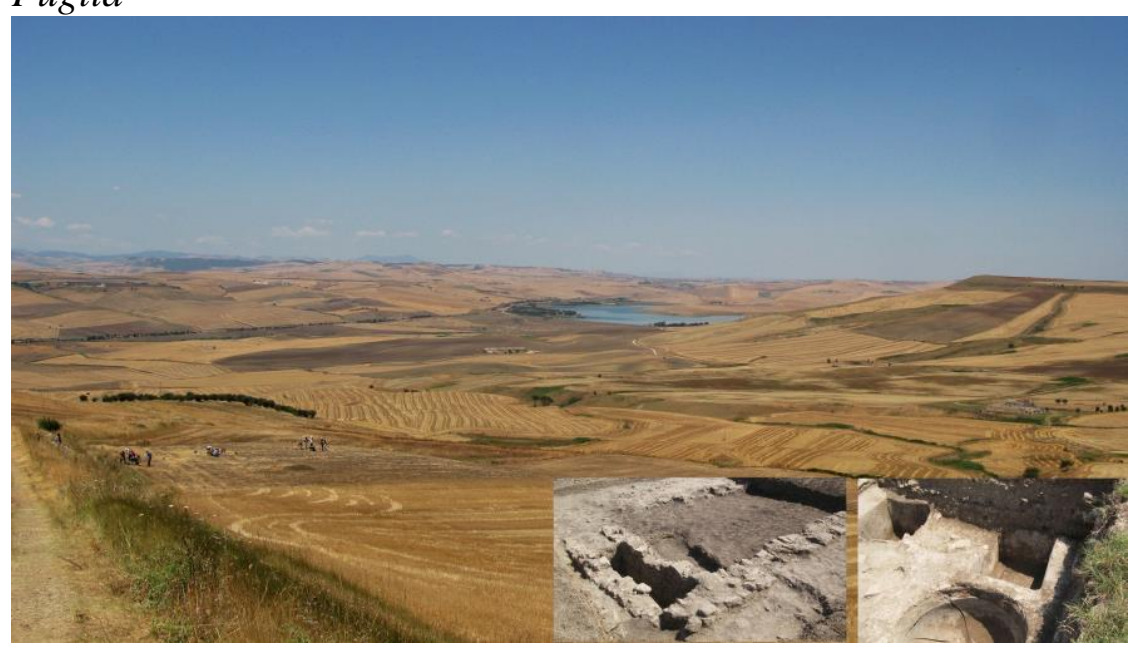

Using investigations of alluvial deposits and springs, and of pollen and macrofossils from these and from the archaeological sites being excavated, we are providing an array of data that will reveal a dynamic picture of the Puglian landscape not only during the transition from the Roman Republic to the Empire approximately 2,000 years ago, but for much of the Holocene. This, in combination with other studies underway in the region, should eventually provide a more complete picture of the lives of southern Italians at the beginning of the first millennium AD.

The Basentello and Bradano river valleys have been a frontier zone in southern Italy for thousands of years and even today, continues to be a frontier zone between the regions of Puglia (ancient Apulia) and Basilicata (ancient Lucania) (Figure 2). It also served as a corridor linking the coastal sites along the Ionian coast in the south to those of the Tavoliere to the north 
(McCallum and Hyatt, 2014. The medieval and early modern drove road running from Metaponto to the Tavoliere via Monte Serico may have existed in the pre-Roman Iron Age (Small 2011, Favia et al. 2005). During the pre-Roman Iron Age, archaeologists and historians have proposed that Peucetians and Daunians (speakers of Messapian, an extinct Indo-European language, possibly related to the Illyrian or Albanian language family), as well as the Lucanians (who spoke Oscan, an Italic language related to Latin) settled in the region. A local, hybridized, archaeological style of late geometric and sub-geometric pottery known as the Bradano Valley style developed in the area. The area lay at the northern frontier of the coastal Greek colonies along the Ionian Gulf to the south. There was a high level of interaction among all cultural groups (Horsnaes, 2002, Carter 2006), and it is clear that this region saw cultural hybridization (McCallum and Hyatt 2014). With respect to the Roman period, the archaeology at the sites of San Felice and Vagnari provide evidence for cereal agriculture, viticulture, oleoculture, the harvest of native plants, and herding of ovocaprines and cattle (McCallum and vanderLeest 2014, McCallum et al. 2011). The nature of landscape dynamics during these periods is little known (Campbell et al. 2011, McCallum et al. 2011).

Figure 2. The Study Area in Classical Times with the Location of the San Felice Site and Other Classical Sites

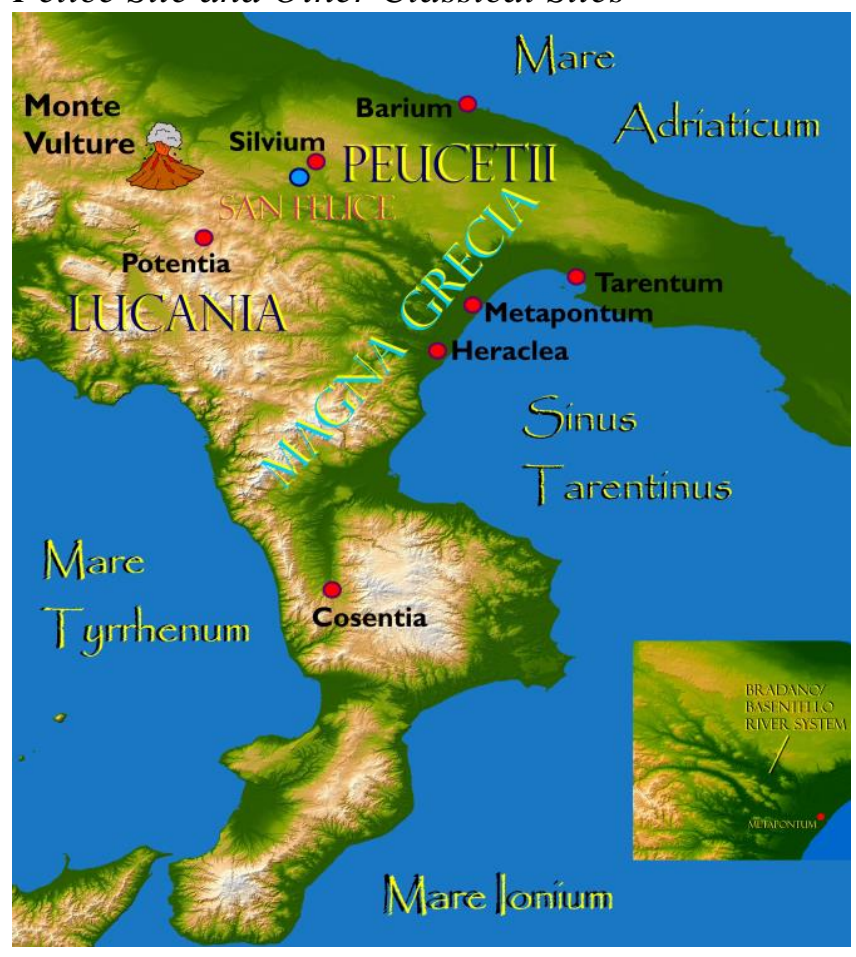

As Rome's power ebbed, the Byzantine Empire assumed control of the region. During the $8^{\text {th }}$ century AD, it endured the Emirate of Bari, a 25-year long occupation by North African Muslims (Musca 1964). The Normans assumed domination of the interiors of Apulia and Lucania, i.e., the Basetello and Bradano river valleys, after defeating the Byzantines at the 
Battle of Montepeloso in 1064 (Brown 2003). Until 1861, when Italy was unified during the Risorgimento, the Kingdom of Naples and the Kingdom of the Two Sicilies vied for control of the region (Hearder 1983, Crawford 1905). As in the past, the region is still considered as a distinctly unique portion of Italy, the Mezzogiorno.

\section{Setting}

The Roman villa site at San Felice is located within the Comune di Gravina in Puglia (ancient Silvium), approximately $10.7 \mathrm{~km}$ to the west of the town center, and roughly $3.5 \mathrm{~km}$ to the east of the Basentello River, which also forms the boundary between the regions of Puglia, to the east, and Basilicata, to the west. The site lies just north of what was once Magna Graecia, the Ionian coastal region colonized by the Greeks. Prior to the arrival of the Romans, the territory where the villa lies, was probably controlled by the Peucetians from the nearby proto-urban center of Silvium (Small 2011).

Today the region around San Felice is characterized by flat-toped, rolling hills dissected by streams and small rivers that have cut several hundred meters into what is a large plateau of deposits uplifted during the mid to late Pleistocene, and comprised of a spectrum of depositional environments from deepwater marine through shallow coastal to shoreline (beach) conditions coastal and marine origin. Geologically these deposits are part of what is known as the Adriatic - Bradanic Foredeep (Vezzani et al. 2010). Marine deposits, primarily marls of upper Pliocene age, are overlain by marine marls, and coastal deposits, weakly cemented beach sands and conglomerates of lower Pleistocene age. In the immediate area of San Felice the local bedrock geology (Pieri et al. 1968, also Boenzi et al. 2008) consists of three Pleistocene-age formations dating $~ 2$ million years before present. The two lower formations are Calabrian (= marine deposits), while the upper formation is Villafrancian (= continental deposits). The lowest formation, which outcrops on the floor and up to about three-quarters of the way up the sides of the valleys, is a blue-grey, sandy or silty clay with chalk and other carbonate inclusions (Campbell et al. 2011). Above it lies a formation of weakly cemented, yellowish, calcareous and quartzose sands intercalated with lenses of fine gravels and calcarenites. These deposits, which form most of the upper slopes of the valleys, are capped by a stratified, polygenetic conglomerate formation of carbonate and siliceous gravels. It is frequently cross-bedded with lenses of brownish to reddish sand. The conglomeritic layer covers most of the plateau surfaces and, where it outcrops along the plateau rims, it often forms near vertical cliffs, such as can be seen at the town of Irsina west of Gravina. The region is transected by southeast to northwest trending faults. North of San Felice just east of the town of Spinazzola, a major thrust fault rises 500 meters above the landscape exposing the Mesozoic limestone (which underlies the Adriatic - Bradanic Foredeep deposits), and then plunges downward toward 
Metaponto (Metapontum) $100 \mathrm{~km}$ to the southwest where it plunges beneath the waters of the Gulf of Taranto. The regional uplift is recorded in at least eleven uplifted surfaces at elevations of 25 to $370 \mathrm{~m}$ above sea level in the lower $30 \mathrm{~km}$ of the Bradano Valley, and dating between 80,000 and 636,000 years ago (Brückner 1982). The valleys, in turn, have been filled with middle to late Quaternary terrestrial, and occasionally near the coast, marine deposits.

The sediments that comprise the geology of the region are a complex mixture of coastal sands marine clays, and coastal and deltaic conglomerates, that contribute to the formation of an intricate mosaic of surface, and subsurface geology that effect both hydrology, and the edaphic characteristics of the soil. Campbell et al. (2011) suggest that the mixed (nearly intact units of sands, gravels and clays) lithology that characterizes much of the surface and near surface deposits of the area reflects numerous landslides, that have whittled away at the plateau rim deposits and carried them well down-slope, e.g., an extremely large landslide at the Vagnari site, that may have run over $1.5 \mathrm{~km}$ from its detachment point, and had a minimum depth in excess of $15 \mathrm{~m}$.

Since the 1950s the area has been heavily plowed, usually in an up and down-slope manner, so that production of grain, primarily pasta wheat (Triticum durum), can be maximized. Plowing in this manner, has resulted in severe down-slope movement of topsoil exposing the rubified, last interglacial soil, which is easily visible as reddish patches in the dark brown of the upper hill slopes. In just as many places, the underlying, grey, marine/coastal sediments of the Adriatic - Bradanic Foredeep have even been exposed. In the region around Gravina native vegetation comprised of Macchia Mediterranea/ thorn shrub communities, occurs on north-facing slopes in scattered clumps, and along steep-sided stream channels. In places some hilltops are covered by isolated stands of pine-oak woodland, which has been restored, or allowed to go wild as part of the national park development known as the Parco Nazionale dell'Alta Murgia.

\section{The Problem}

Both climate and human activity can affect changes in vegetation distribution, composition, density, and diversity. They can affect spring discharge either directly through modification of springs or pumping of ground water, or indirectly through changing vegetation community composition or structure in the water shed. They can affect the weathering of bedrock, and sediment, and change the type and rate of sediment transport (erosion and deposition processes) by changing the exposure of unweathered material to the elements by changing the slope and exposure. Finally, both can affect soil formation processes through changing the density and composition of the vegetation community. Both drought and land clearance can accelerate erosion. Although technology can allow human populations to adapt to lesser degrees of landscape change, but if 
landscape change is severe enough, even technology cannot mitigate the effects of environmental change, and human societies will suffer or even collapse, e.g., Bronze Age culture collapse in the eastern Mediterranean 3,100 years ago (Weiss 1982).

The problem is that where human population is high; their activities can intervene between climate and the environment to either slow or accelerate the rates of change. In most cases, however, people simply amplify the affect of climate change exacerbating the detrimental effects of climate upon the landscape. People may clear and plow land, or graze animals at a time when climates are drying, and vegetation cover is under stress, thereby accelerating erosion and halting soil formation processes. Therefore, even though climate change by itself might not cause significant destruction of the landscape, the additional impact of people, their farming practices, and animals might accelerate and increase the rate of landscape change.

\section{Paleoenvironmental Record}

Information about the landscape of the Roman period (as well as of the late Quaternary) of southern Italy comes from a series of pollen cores and studies of alluvial records in Basilicata, Puglia, and Calabria provinces and Sicily. Almost nothing is known about the soil chronosequence or record of spring discharge.

\section{Palynological Record}

The reconstruction of the regional climate based upon pollen has been attempted at Lago Grande di Monticchio (Allen et al. 1999, 2000, 2002, 2009, Bauer et al. 2000, Huntley et al. 1999, Watts et al. 1996a, 1996b), Lago Alimini Piccolo (Di Rita and Magri 2009), and Lake Trifoglietti (Joannin et al. 2012) (Figure 3). These records are from several cores taken from different geologies, elevations and vegetation assemblages, and are therefore highly variable, and in some cases contradict each other. In addition to reflecting the diverse environments they come from, they may also reflect the varying degree of human impact in each of these areas. Obviously they reflect differences in the sensitivity of the various pollen records due to their elevational and vegetation settings as well. Another pollen record lying just out of the local region is that of Lake Pergusa in central Sicily (Sadori and Narcisi 2001, Sardori et al. 2008). This record includes a study of fire and its relationship to climate and vegetation dynamics during the Holocene (Sardori and Giardini 2007). 
Figure 3. Location of the Paleoenvironmental Study Sites Mentioned in the Text

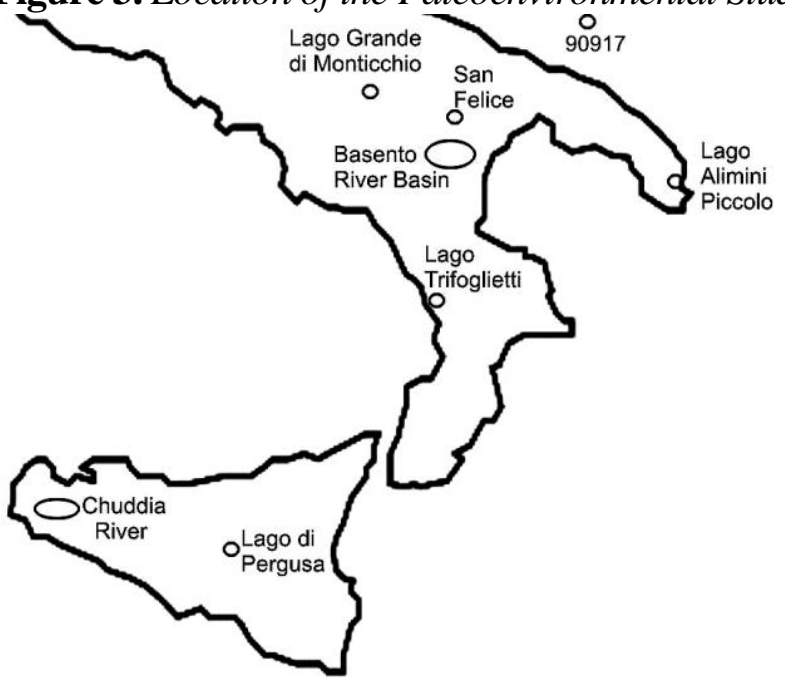

Geomorophic Record

Research conducted by Campbell et al. (2011) describes the geomorphology of the San Felice area, and the research of Boenzi, Piccarreta, and others have concentrated on the alluvial history of neighboring Basilicata region about 35 kilometers to the southwest. Further south in west central Sicily the work of Heinzel and Kolb (2011), provides an excellent description of geomorphic processes that bare striking similarity to those observed in the research conducted in Basilicata Province, and by us in our preliminary research in the Gravina area.

In summary, the erosional history of the central Mediterranean is dependent upon the local Mediterranean climate, tectonics and human impact. These interact to create the gross morphology and surface conditions of the landscape. However, lithology, in particular sediment size and clay mineralogy also play an equal role in determining the nature of surficial processes. For example, Summa and Giannossi (2013) in their study of "badlands" in Basilicata Province found that soils with higher clay content had greater potential for erosion than slopes in the same area with lower clay content. They suggest that this related to permeability. The greater the permeability the more stable the slope. They also found that slightly higher values of $\mathrm{pH}$, higher sodium absorption ratios, higher sodium percentages and especially higher exchangeable sodium percentages were characteristic of slopes that were highly eroded. Generally, in the Mediterranean area most parent materials are silt-dominant, with clay as the second particle size, and sand generally very poorly represented (Edoardo et al. 2012). As indicated above, the middle and lower elevational areas around San Felice are predominated by marine clays. Upper elevational areas are dominated by coastal conglomerates, and sandy coastal and beach deposits. The lower slopes are more potentially more susceptible to rapid erosion around San Felice because they are comprised of these more easily erodible clays. When these erode they undermine and destabilize the upper slopes, 
which are comprised of sands and cemented conglomerates. Previous episodes of massive and abundant landslide activity dated to $40 \mathrm{k}$ yr BP seem to correspond to wetter climatic episodes (Boenzi at al. 2008, Piccarreta et al. 2011).

\section{Preliminary Research}

\section{Methods}

In June 2012, a graduate student and I were invited to southern Italy by a team of Canadian, and British archaeologists to assist them with description of the landscape setting of a Roman villa owned by the Roman emperor, Augustus Caesar, and an associated village, and cemetery complex west southwest of the town of Gravina in Puglia. Initially we were there to survey the countryside surrounding San Felice for suitable exposures and springs to sample for pollen and macrofossils that would provide us with evidence of what the local vegetation may have looked like in the $1^{\text {st }}$ millennium A.D. During our survey we located at least five alluvial exposures, three spring mounds, and two active springs to sample (Figure 4). We collected over 95 sediment samples from two exposures (Arroyo Italiano 1, Vagnari 1), and trenched and took five cores one of the spring mounds (Baron Spring) with a split-rod sampler. During our survey we identified other areas to sample, but decided to wait until the summer of 2013 to conduct further sampling (Figure 4).

Figure 4. Outcrops and Springs Identified for Sampling in the Gravina in Puglia Region during the Summer of 2012 and 2013; These Include Holocene, Pleistocene and Upper Pliocene Sites

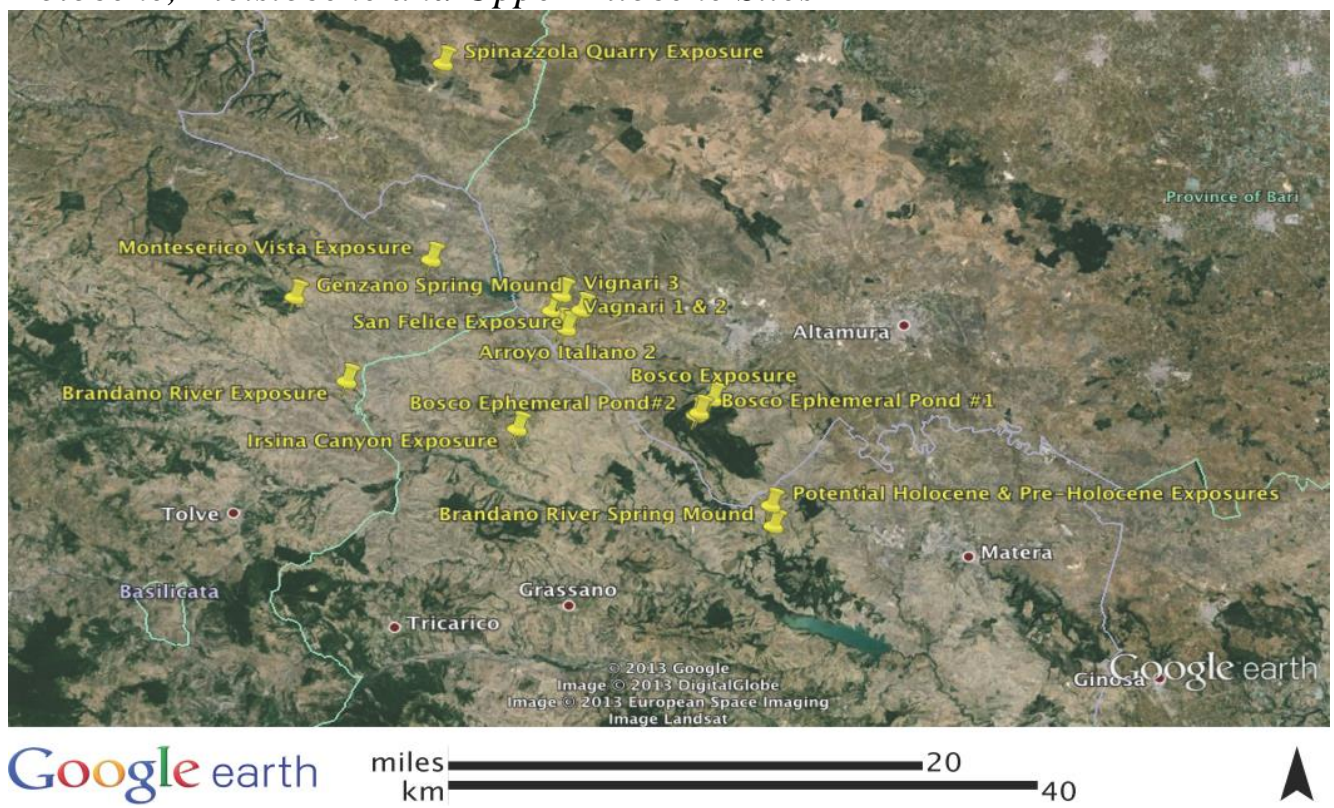


We submitted three samples for radiocarbon dating at Beta Analytic, Inc. Professional Radiocarbon Dating Services in Miami, Florida. In addition, for comparison, we processed 24 sediment samples from two exposures for grain size parameters. Nine were processed at the soils laboratory at Texas A \& M University using a Beckman Coulter Inc. Multisizer 3 Coulter Counter. And fifteen we processed at the Geology Department at California State University, Bakersfield with a Malvern Mastersizer 2000 laser particle analyzer.

In summer (June and July) of 2013 with a crew of four students, additional sites that had been identified in western Puglia and central and eastern Basilicata provinces were sampled (Figure 4). In addition, to middle to late Holocene exposures we also sampled much earlier sediments so that we could put our study into a regional context. These sites would also characterize local sediments so that extra-local sediments, e.g., African dust, could be identified. We also identified over fourteen additional sites to sample, and two lakes to core. We collected: 1) two exposures spanning the entire Holocene (Arroyo Italiano 1, Vagnari 2); 2) Another exposure just above the San Felice villa site to document a late Holocene landslide (San Felice Slide Exposure); 3) Three exposures of coastal and beach sands one of which lay just above the villa site and would have been the origin of the landslide which may have buried it in the $1^{\text {st }}$ century A.D. (San Felice Headwall, Monteserico Vista, and the Bosco Site); 4) Two exposures of marine clays (Vagnari 3, and the Brandano River Site) as well, for the purpose of grain size and chemical/mineralogical comparison with our other sediments. In addition a series of samples for radiocarbon dating were collected. The sediment samples were sent to our USDA Permitted lab at the University of Nevada, Reno where they are being analyzed. The radiocarbon samples were sent to the CEDAD - AMS Radiocarbon Dating and IBA Facility at the University of Lecce, in the Department of Engineering and Innovation in Lecce, Italy in November 2013. Unfortunately, all of our samples were contaminated by contamination in the CEDAD laboratory due to biomedical research that is being conducted there.

We returned to southern Italy the summer of 2014 to resample exposures for AMS dating. However, during the ten months since our first visit to these exposures, dramatic incision of some of the alluvial channels had occurred. This incision was the result of the torrential rains that struck Italy beginning in September 2013 (Davies 2013b). In some cases these rains fell at rates of over $90 \mathrm{~mm}$ per hour (Davies 2013a) and caused largescale flooding resulting in tremendous property damage, as well as loss of life.

The incision that my colleague and I witnessed varied from 1 to 2 meters in small streams feeding into the Basentello River west of Gravina in Puglia (Figure 5). This equals another 2,000 years of record. 
Figure 5. The Arroyo Italiano 2 Exposure, which was Sampled Last Summer, had to be Sampled again this Summer to Recover an Additional 2 Meters of Sediment Samples at the Base of the Column

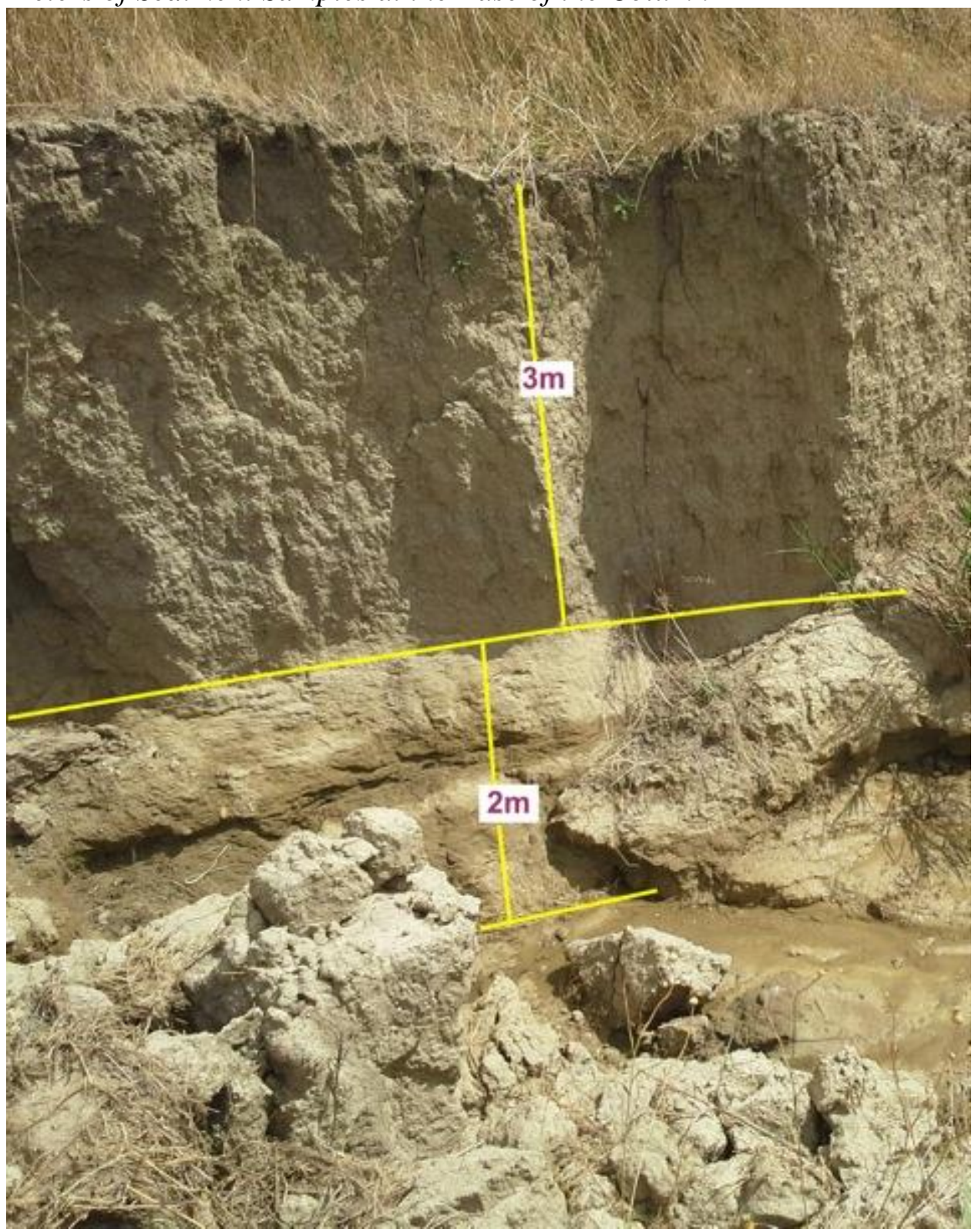

In the bottoms of most of these streams we found armoured mud balls (Figure 6), a clear indication of torrential rains and high stream flow velocities. These where found in great abundance wherever the channel was wider and the stream gradient less steep. The size of these mud balls ranged between five and $30 \mathrm{~cm}$. The larger mud balls indicate either very high stream flow estimated at about 4 meters per second based upon the size of the mud balls, or a highly viscous debris flow. 
Figure 6. Armored Mud Balls in the Channel of Arroyo Italiano 2; the Pocket Knife Is $10 \mathrm{~cm}$ or Just Under 4 Inches Long

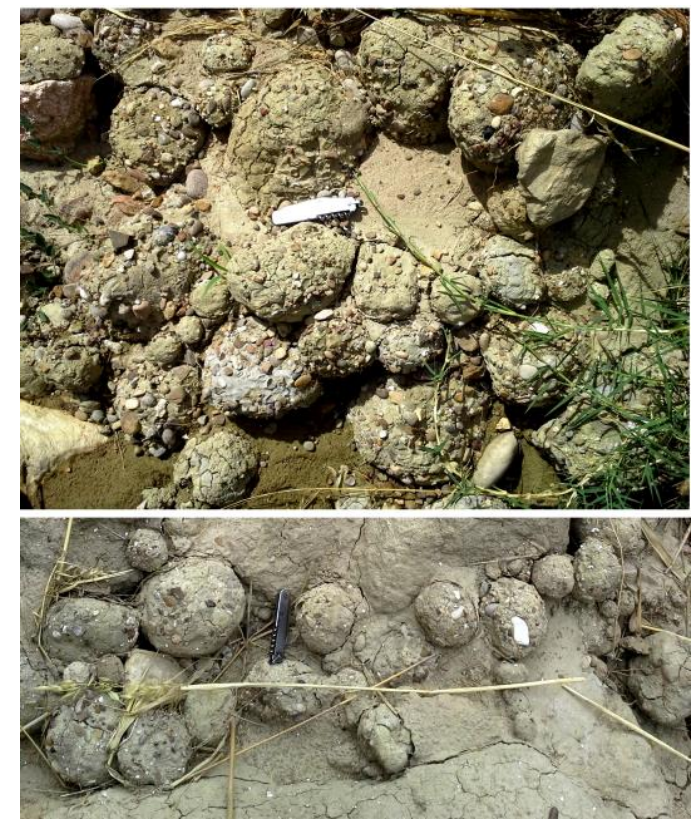

Every one of the alluvial exposures that we had sampled in the summer of 2013 had to be sampled this summer for newly exposed profile below the depth that we had sampled previously. In most cases we suspect that an additional 2,000 to 3,000 years of additional exposure had been revealed by the down-cutting of the fall of 2013 and the winter of 2014.

We expected much of the eroded sediment to be deposited downstream in the lower gradient sections of the Basentello River. However, we found no evidence of deposition in the lower stream drainages. Apparently most of the sediment had been washed directly into the Gulf of Taranto. News photos taken of the very muddy coastal waters surrounding Italy following the storms of this winter support this supposition.

The cutting of the previous winter not only revealed more exposure, but also an early Holocene soil with strongly developed argillic horizon. In most cases the upper horizons of this soil had been eroded by an early or middle Holocene erosional event. Finally, in the deepest portions of the newly exposed sections, pond sediments, rich in tiny bivalve and gastopod shells was uncovered. This unit was found in several of our stream drainages suggesting an episode of deposition, and ponding sometime in the early Holocene, or perhaps late Pleistocene.

\section{Results and Discussion}

\section{Field Observations}

The alluvial exposures (Arroyo Italiano 1 and 2, and Vagnari 1 and 2) display a pattern of recurrent flood events spanning at least 10,000 years in the cases of Arroyo Italiano 1 and 2 and Vagnari 2 (Figure 7). Almost all 
alluvial exposures contained sequences of units with gravels or coarse sands at the base and fining upward to silts or clayey silts.

In most cases a soil was developed in the upper portion of each of these units. In general, the soils were weakly developed, however two of the soils, were strongly developed (Figure 8). Calibrated dates indicate the age of the upper soil at $\sim 2,100$ cal B.P. and the most strongly developed soil at the base of the exposure to be just before $8,400 \mathrm{cal}$ B.P.

Figure 7. Local Exposures of Major Sediment Types at the San Felice Site Complex (Not to Scale)

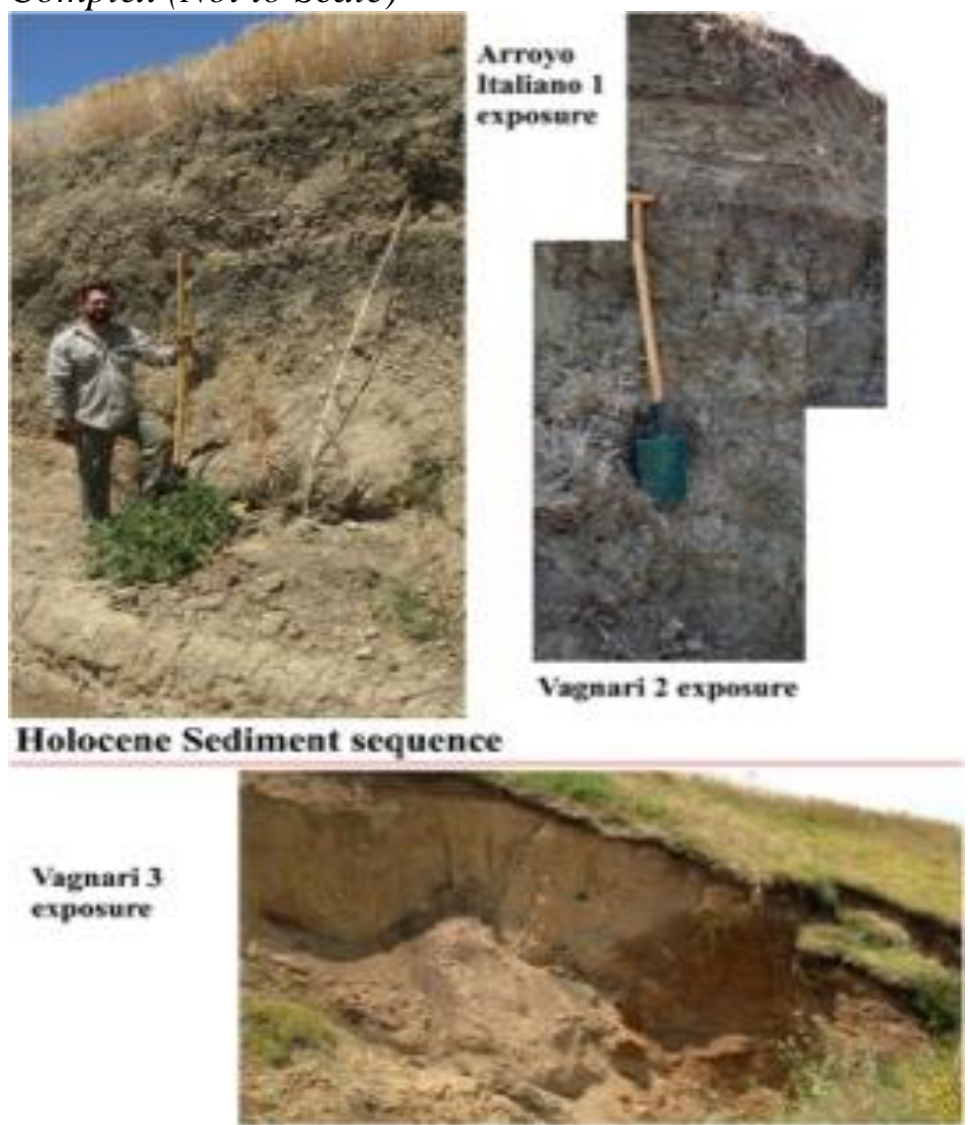

Pleistocene Interglacial soil and Glacial cut and fill

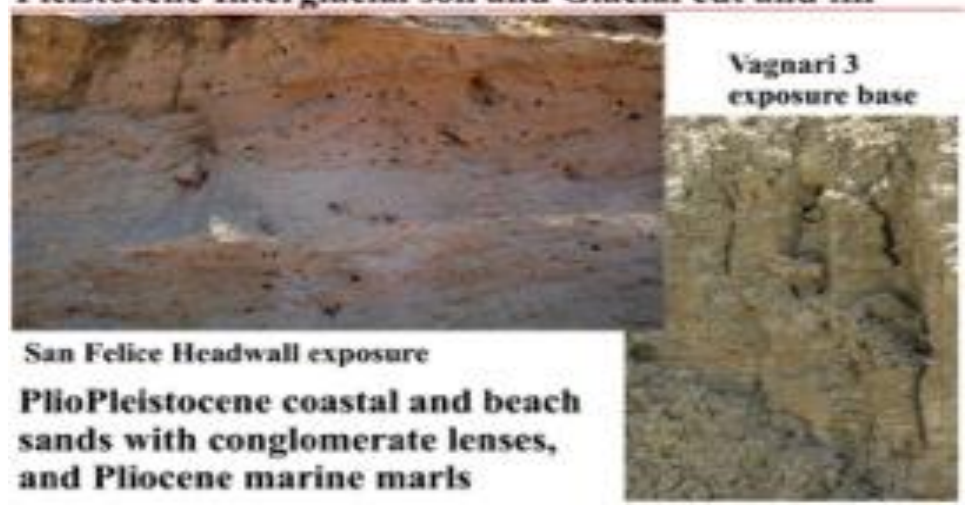


Figure 8. Arroyo Italiano 1, Exposure 2 Showing the Upper Well Developed Soil and the Newly Revealed Very Strongly Developed, Early Holocene Soil

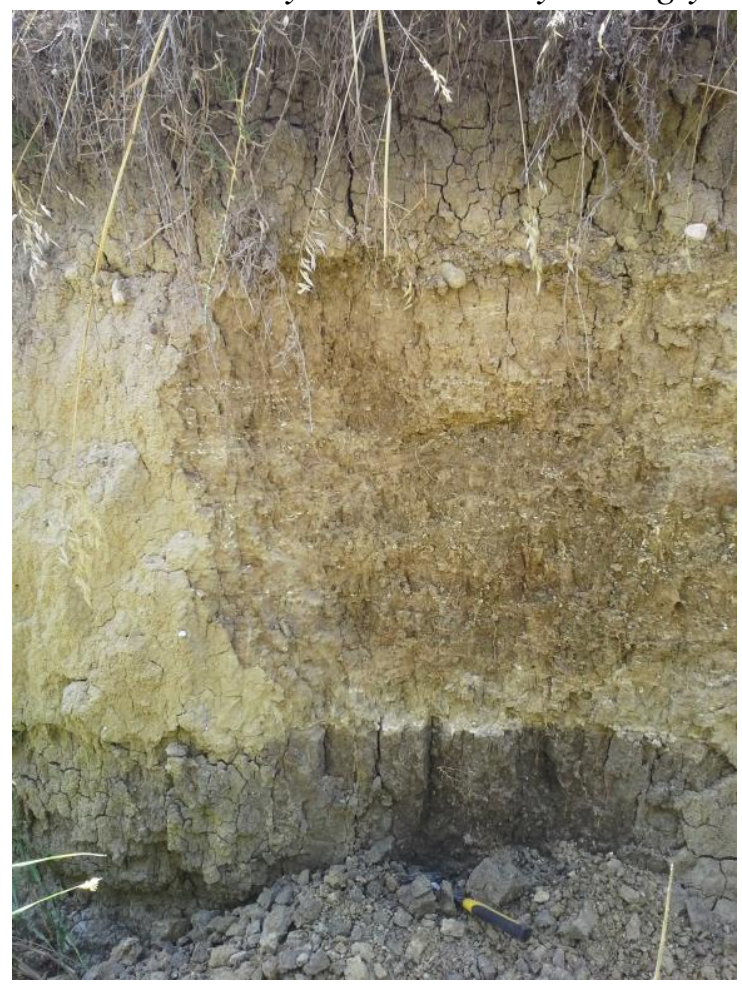

We also observed a change in the number of these units in alluvial exposures as we surveyed from the upper portions of these drainages down to the Basentello River Valley floor. In the upper portions of drainages there is little evidence of any flood episodes, because these are areas of head-ward cutting where alluvial channels have not previously existed. The upper slopes are characterized by massive surface erosion resulting from extensive plowing. We noted in some areas between one to two meters of topsoil removal at the top of many slopes as measured against the soil surface at the base of fence lines dating to the 1950s.

In the middle portions of the small drainages five to six and perhaps more episodes of flooding were observed in alluvial exposures. At points in the drainages just above the valley floor, the number of flood events observed decreases, but their scale increases. It seems that at these points in the stream drainages, single large flood events have destroyed the evidence of earlier, small-scale events that are preserved further upstream. This difference will enable us to reconstruct not only the full sequence of Holocene flooding in the area, but will also provide us with a measure of the varying magnitudes of these floods. Interpretation of flood strength is also provided by the occurrence of large gravels at the base of most of the flood episodes in the lower portions of the drainages. Gravels are either missing or much smaller in size in the middle portions of the drainages.

Similar cycles of deposition occur in the erosion/deposition sequences studied about $25 \mathrm{~km}$ south of San Felice in the Basento River (Boenzi et al. 2008). I also observed this same pattern of large-scale flood events $50 \mathrm{~km}$ to the south near the coast in exposures studied by Dr. Daniela Sauer (the 
University of Hohenheim) east of the town of Pisticci near the tops of terraces overlooking the Basento River. I have also observed such cyclical flood units in alluvial exposures on the Bradano River southeast of San Felice. Similar units have also been studied by Dr. C. Heinzel in alluvial sequences of central Sicily in valleys in the Nebrodi and Polizzo Mountains (Heinzel 2004, Heinzel and Kolb 2011). There he suggests that the alluvial sequence which was dominated by coarse-grained (cobble or boulder) deposits was due to flash-flooding primarily as a result of land-use practices occurred during the occupation of hilltop forts in that region of Sicily. However, this cannot be the only cause, because some of our flood units are much older.

Figure 9. The Vagnari 2 Exposure with Multiple Flood Units and Soils of Varying Development Clearly Visible

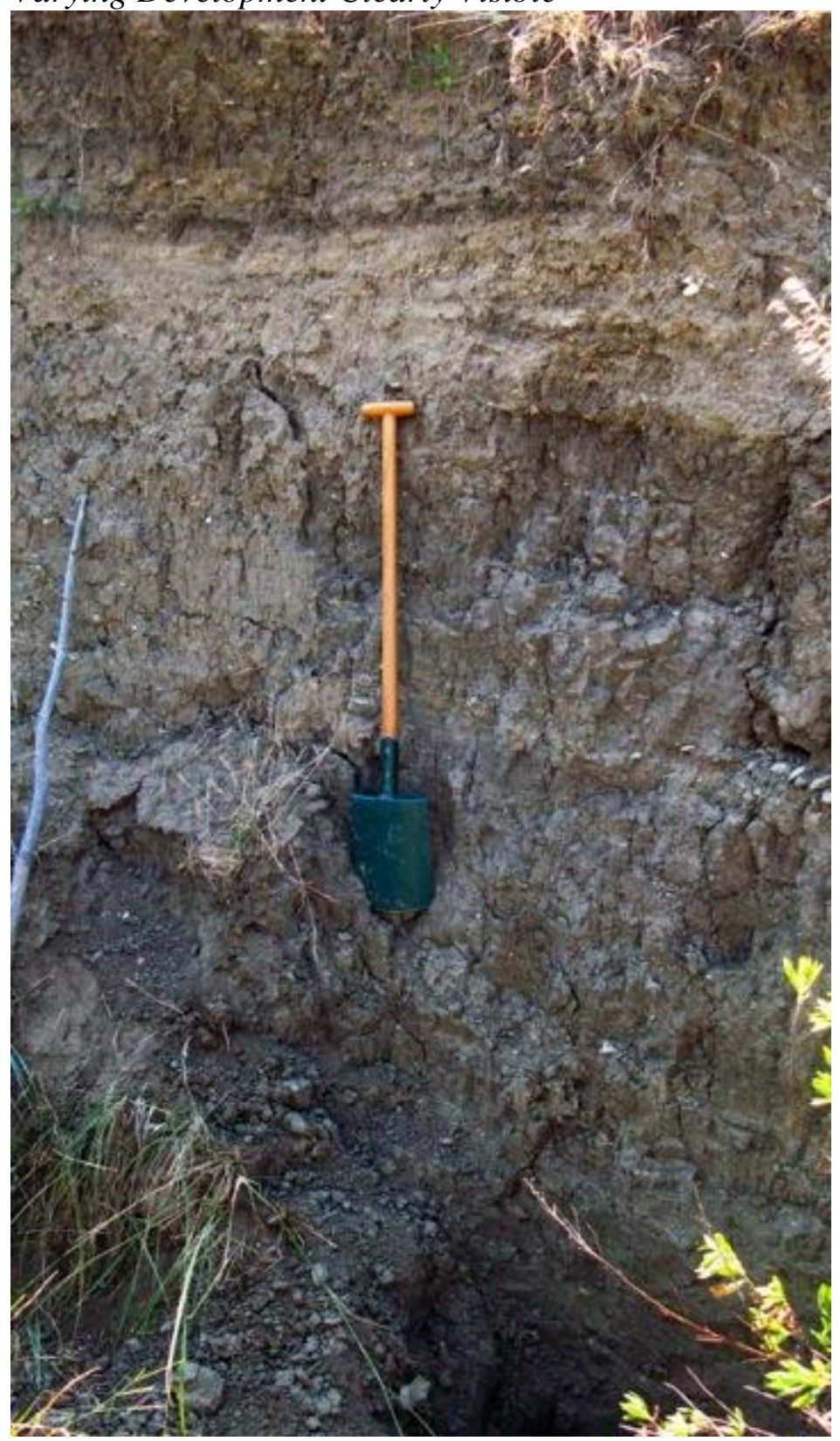


Based upon our initial radiocarbon dates at Arroyo Italiano 1 (Table 1), we have identified at least three major flooding events during the last 8,400 cal B.P. and perhaps as many as four to five smaller scale events during the same period in the Vagnari 1 and 2 exposures (Figure 9). All flood units have the same pattern of coarse to fine sediment gradation. The major events are characterized by cobbles at their base, whereas the minor events are usually characterized by coarse to medium sands. This is confirmed by the preliminary sediment size analysis from both Arroyo Italiano 1 and Vagnari 1 (Figure 10). At the base of all of our full Holocene alluvial exposures (in the middle and lower portions of the stream drainages) lies a massive, gleyed, clayey, silty sand, occasionally with small mollusks. In the Arroyo Italiano 1 exposure this unit lies well below a radiocarbon date of 8,400 cal B.P. We expect that when dates are run on this unit it will be latest Pleistocene in age.

Figure 10. Grain Size Distributions of Vagnari 1 Sediment Samples
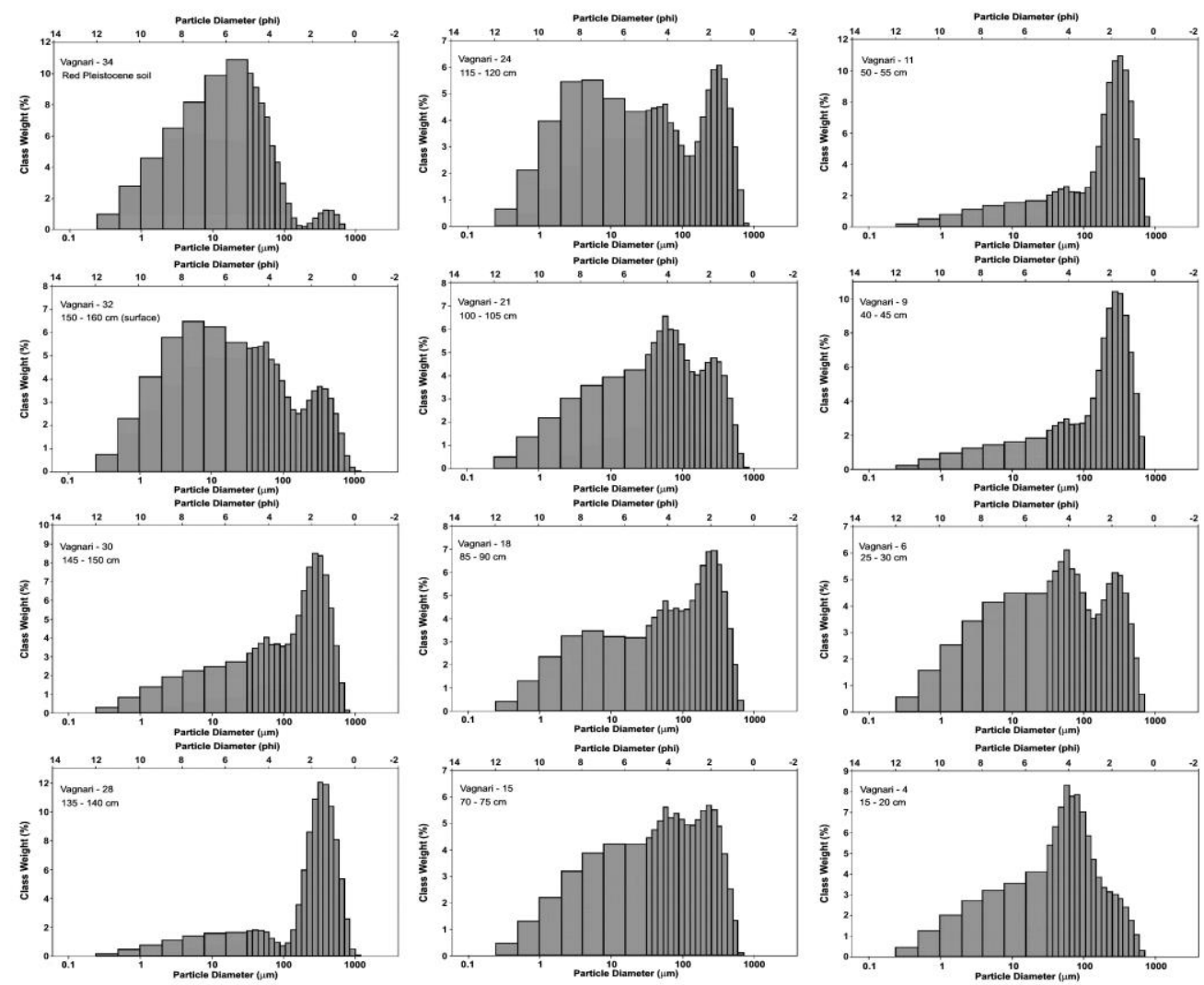

As noted above we observed that many of the flood units, in particular the major ones, have soils that formed in their upper portions after deposition had ceased. These range from poorly developed soils with incipient A horizons, and weakly developed B horizons, to soils with strongly developed A and B horizons, and distinctive B and C horizons with strong carbonate accumulation. In the upper strongly developed soil the A and $\mathrm{B}$ horizons are thick (in excess of $40 \mathrm{~cm}$ ), and the A horizon has considerable accumulation of organic material indicated by its color. The $\mathrm{B}$ 
horizon has a sub-angular blocky to columnar structure and well-developed clay coatings on the peds. Thus far, the dates indicate that the most strongly developed soil began forming prior to $8,400 \mathrm{cal}$ B.P. and the upper strongly developed soil just after 2,100 cal B.P. (Table 1). Carbonate concretions occur in the upper strong soil B horizon.

Table 1. Radiocarbon Dates from Southern Italy

\begin{tabular}{|l|l|l|l|l|l|l|}
\hline $\begin{array}{l}\text { Sample } \\
\text { \# (Beta) }\end{array}$ & $\begin{array}{l}\text { Sample } \\
\text { Description }\end{array}$ & $\begin{array}{l}\text { Measured } \\
\text { R.C. } \\
\text { Age B.P. }\end{array}$ & $\begin{array}{l}\mathbf{C}^{\mathbf{1 3}} / \mathbf{C}^{\mathbf{1 2}} \\
\text { Ratio } \\
\text { o/oo }\end{array}$ & $\begin{array}{l}\text { Corrected } \\
\text { R.C. } \\
\text { Age B.P. }\end{array}$ & $\begin{array}{l}\text { 2 Sigma } \\
\text { Calibration } \\
\text { Cal B.C. } \\
\text { \& Cal B.P. }\end{array}$ & $\begin{array}{l}\text { Mean Age } \\
\text { Cal B.P. } \\
\text { Fairbanks }\end{array}$ \\
\hline 338002 & $\begin{array}{l}\text { Major Soil } \\
\text { (top) }\end{array}$ & $2080+/-30$ & -24.1 & $2090+/-30$ & $\begin{array}{c}200-40 ; \\
2140-1990 ;\end{array}$ & $2054+/-48$ \\
\hline 338003 & $\begin{array}{l}\text { Major Soil } \\
\text { (top) humates }\end{array}$ & $2570+/-30$ & -29.1 & $2500+/-30$ & $\begin{array}{c}780-520 ; \\
2730-2470 ;\end{array}$ & $2618+/-86$ \\
\hline 338004 & $\begin{array}{l}\text { Top of } \\
\text { lower soil }\end{array}$ & $7560+/-30$ & -24.8 & $7560+/-30$ & $\begin{array}{c}6460-6400 ; \\
8410-8340 ;\end{array}$ & $8377+/-16$ \\
\hline 336768 & $\begin{array}{l}\text { Baron } \\
\text { Spring base }\end{array}$ & $3440+/-30$ & -24.6 & $3450+/-30$ & $\begin{array}{c}1880-1840 ; \\
3830-3790 ;\end{array}$ & $3702+/-47$ \\
& & & & & $1830-1690 ;$ \\
& & & & & & \\
\hline
\end{tabular}

In most sections the tops of these soils are truncated by a flood event so we do not have an exact lower age estimate of their formation. There are other soils between these two soils and at least one above the 2,100 cal B.P. date, but we are still awaiting the results of these radiocarbon analysis. In particular, there are four to five soil units in the Vagnari 2 exposure in the drainage lying below the San Felice site (Figure 9).

Just above the Basentello River a series of springs are commonly found at the contact between the marine marls and the Pleistocene coastal sands and conglomerates. However some occur at the bases of conglomerate slabs that were detached from the tops of the plateaus by massive landslides. We cored "Baron" spring, so-called because it lies on the land of Barone de Gemmis, and shown to us by his estate manager Signore Lucio. Most seeps and springs show little vegetation diversity, reflecting a recent or ephemeral nature. "Baron" spring was covered with a rich assortment of sedges, cattails, and other wetland plant species. Although dissected by several channels, we were able to obtain a meter long core from an un-eroded remnant of the spring. We identified three episodes of increased spring discharge evidenced by peat layers. The earliest date, 3,700 cal B.P., on increased discharge from Baron Spring was on organic material just above the base of the core. Two more undated episodes lie between that date and the surface of the spring.

\section{Laboratory Results}

The results of preliminary grain size analysis on samples from Arroyo Italiano 1 and Vagnari 1 collected during our first Summer in Italy confirm 
not only the trend from coarse to fine grain size in the flood units which we observed in the field (Figure 10), but also revealed that many of the sampleshave grain size distributions that are bimodal and in some cases trimodal. In Figure 10 the sample in upper left is of a Pleistocene soil. Samples are arranged in stratigraphic order from the Surface (\#32) to near the base of the exposure (\#4). Depths are measured from the base of the exposure. Grain size of 62.5 microns is the boundary between sands and silts and 3.9 microns between silts and clays. Silts and clays predominate, but occasionally samples dominated by sands occur. These signal higher stream velocities.

This means that many of the sedimentary units in the Arroyo Italiano and the Vagnari 1 exposures come from mixed sources. Most samples have a large medium to fine sandy component, but many have a large silt component instead. However, some samples have a very abundant clay component, which at times is greater than either the silt or sand components in the samples. The sands probably have their ultimate origin in the early Pleistocene coastal and beach sand deposits at the tops of the plateaus. The silts and clays are probably a combination of sediments weathered out of the lower Pleistocene deposits some of the silts and especially the clays may have their origin in the silts and clays that the sirocco winds blow across the Mediterranean from North Africa. This hot humid south or southeast wind that blows into southern Italy, Sicily, and the Mediterranean islands during the spring or the fall, and originates in the Sahara Desert as a dry dusty wind but becomes moist as it passes over the Mediterranean (Blanco et al. 2003).

Major sediment sample parameters calculated from the grain size analysis are plotted below (Figure 11). They reveal the cyclical pattern of deposition with coarse materials at the base of the deposit, grading to finer materials at the top of each cycle. Generally, except for the gravels at the bases of the units, the sediments at Arroyo Italiano have a finer mean than those upstream at Vagnari. Whereas the means often lie around medium silt at Vagnari, they are usually in the fine silts at Arroyo Italiano. Although the sorting at both localities is extremely poor, it tends to be slightly better sorted at Vagnari. Sediment samples at Vagnari range between platykurtic and mesokurtic, whereas samples at Arroyo Italiano tend to be more often leptokurtic to very leptokurtic. Although samples at both sites tend to be positively skewed, there are several at Arroyo Italiano that are very coarsely skewed. Upstream at Vagnari, sands and coarse silts settle out, but the finer silts and clays seem to have been carried further downstream. It is the greater clay content at Arroyo Italiano that makes its samples both leptokurtic and more finely skewed. The sedimentology of the Arroyo Italiano flood units suggest debris flows that carried sediments ranging from clays to gravels. When the slope gradient became more gradual the gravels and sands were deposited, and then as the flood subsided, the silts and clays were deposited on top of the units downstream. 
Figure 11. Grain Size Parameters for Arroyo Italiano (Left) and Vagnari 1 (Right); Samples Are Arranged By Depth (Samples Are Numbered from the Base of the Profiles to the Top)
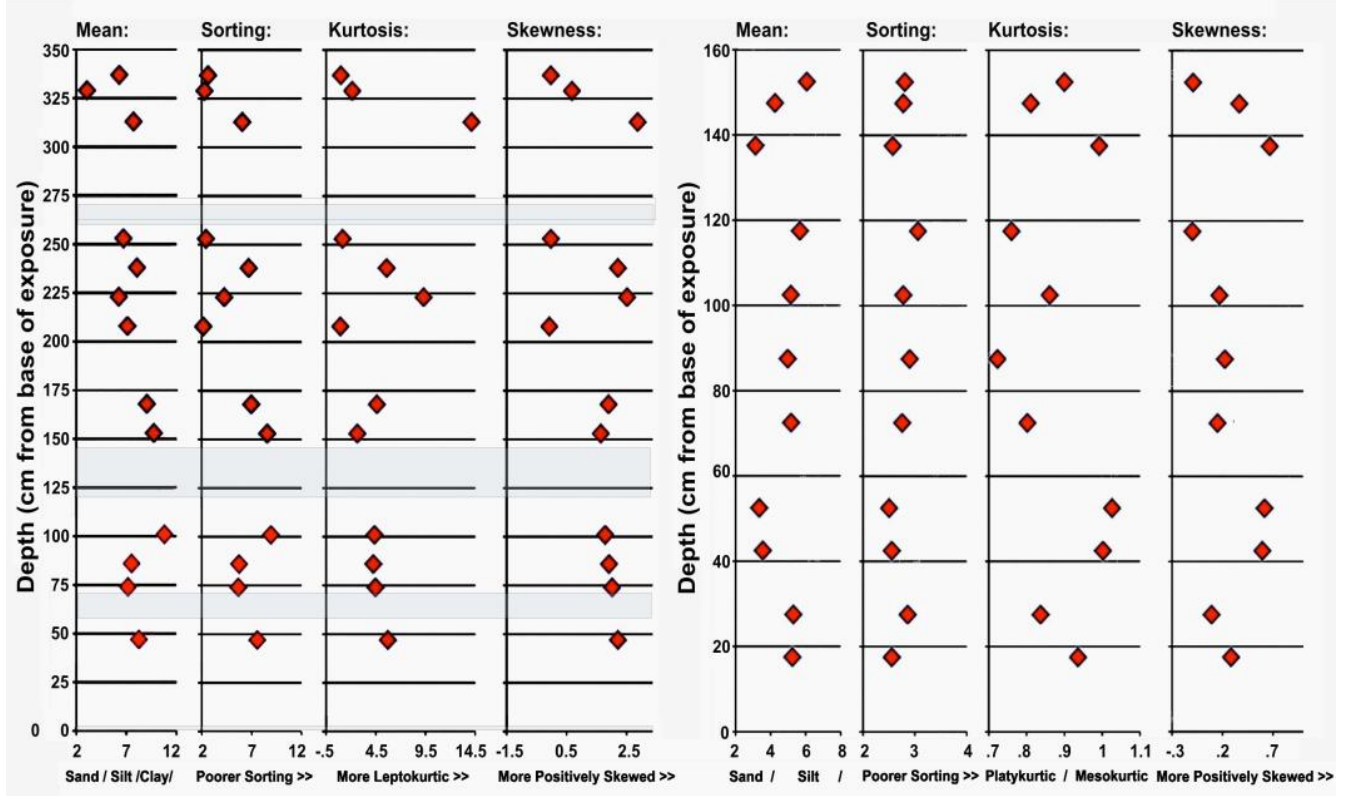

Climate, Spring Discharge, Vegetation, Erosion and Deposition and Soils

Although our data are preliminary, there are some correspondences emerging between the alluvial records described by Boenzi at al. (2008) and Piccarreta et al. (2011) in Basilicata Province southwest of the San Felice region, and the landscape record that is revealed in our study. There appears to have been an episode of alluvial deposition that began just prior to our earliest soil date at a about 8,400 cal B.P. (Piccarreta et al. 2011 Figure 5). However, beginning about 4,100 cal B.P. a period of significant flooding is revealed in the alluvial records of Basilicata (Piccarreta et al. 2011 Figure 5, Boenzi at al. 2008 Figure 7). The date of about 3,700 cal B.P. on peat at the base of Baron Spring may date the point when ground water recharge from wetter climate was significant enough to begin discharging from local springs. This continues until about 3,000 cal B.P. when a drier episode is proposed, lasting until about 2,500 cal B.P. (Piccarreta et al. 2011 Figure 5). At that point a period of cool, moist climate resulted in repeated flooding events and a rise in the regional water table. It is during this period, which appears to be characterized by the greatest degree of cool moist conditions in the late Holocene, that the upper, 2,100 cal BP soil in the Arroyo Italiano/Vagnari exposures developed. Thereafter, renewed drier conditions resulted in erosion, and the truncation of the top of the upper Arroyo Italiano/Vagnari soil. Deposition of the sediments in the upper portion of these two profiles may date to the three episodes that Piccarreta et al. (2011) record. Formation of the weaker upper-most soil probably coincides with the Little Ice Age event about 300-120 cal B.P. 
Piccarreta et al. (2011) believe that human impact in the Basilicata region remained low until about 3,700 cal B.P. or the middle of the Bronze Age. From that point until about 2,700 cal B.P. it was high. Then from about 2,700 to 1,900 cal B.P. during the Greco-Roman period human impact became very high. During the Byzantine and Medieval period from 1,900 to 500 cal B.P. human impact was slightly less, but still high. During the last 500 years they suggest that human impact was again very high. If the suggested intensity of human impact of Piccarreta et al. (2011) is correct, it would suggest that soil formation, except for that prior to 4,000 years ago, occurred, either despite human activity, or because of it.

\section{The Climate-Vegetation-Geomorphology-People Model}

Climate variation underlies all landscape transformation. However, it is the geology, topography, and vegetation that determine the final outcome of climate's input. It is their susceptibility and response to climate that shape the landscape. In particular, how they are affected by climate will determine the resulting rates of weathering, erosion and deposition of sediment on the landscape. Climate also determines the kind and density of vegetation, which determines the vulnerability of the ground surface to erosion. And the amounts and nature of precipitation will determine the nature of erosion and its magnitude. Changes in the ground surface in turn effect the stability of the vegetation community and can result in changes in that community that can then accelerate processes of erosion.

When people are added to the equation, rates of erosion and deposition deviate from those expected in a natural system. The degree of deviation depends upon the location of, scale of, and nature of human activity on the landscape. If human populations are low, then changes in the natural system may be minimal. However, even if populations are low, if their activity changes the natural vegetation cover, or if the point at which their activity is concentrated on the landscape is at a sensitive point (unique geology, vegetation, or slope) the natural system may be impacted out of proportion to human population size. On the other hand larger populations might not impact the environment as much if their activities have a minimal impact upon the environment, or occur on the landscape in areas that are less sensitive to disturbance.

The dynamics of climate change, varying vegetation response, and the nature of human impact is a complex problem. At least part of the problem has been addressed by research in the American Middle West in the 1950s. A diagram relating climate and erosion/deposition and vegetation was developed by geomorphologists Langbein and Schumm (1958). I have modified their original diagram to fit the southern Italian problem. Figure 12 shows the relationship between sediment yield effective precipitation (ppt), and vegetation cover is plotted with the dashed line on the left (modified after Langbein and Schumm 1958). Following the suggestion of Wilson (1973) the larger dashed line on the right indicates the relationship when human activity becomes significant. The high point of this line will move 
right with increased denudation of the landscape, and left with decreased human activity approaching the black dashed line which is the "natural" state. The magnitude of sediment yield will increase with human activity, because not only is vegetation covered destroyed, but under a higher precipitation regime. Today the lowest ppt is just under $400 \mathrm{~mm} / \mathrm{year}$ in southern Italy, there is no equivalent to the desert shrub community which is found in the North American West. Southern Italian vegetation types are plotted by their ppt range at the top of the diagram, except for that at the highest elevation South Apennine Mixed Montañe forest where ppt ranges from 1,800 to over 2,100 $\mathrm{mm}$ per year.

We suggest that under a natural state we might expect erosion to be higher under the precipitation regime and vegetation cover of the Tyrrhenian-Adriatic sclerophyllous and mixed forest vegetation communities, and lower under the precipitation regime and vegetation cover of the Italian sclerophyllous and semi deciduous forest vegetation communities. It might approximate that trend of the black dashed line in Figure 12. Erosion rates in a natural southern Italian ecosystem might never approach the highest along the black line. However we suggest that as human activity increases the erosion curve might be expected to migrate to the right as we have illustrated with the second dashed curve on the right. I would expect that as woodland and forest disturbance increased, erosion rates might increase and be magnified under regimes of higher rainfall when under normal conditions it would be expected that the natural forest cover would protect the ground surface against erosion. Depending upon the degree of human impact, we would expect erosion rates to increase sharply under higher and higher rainfall regimes. That is, as human activity increases, we would expect erosion to increase, and even exceed "normal" sediment yields. Therefore, in this model, the position of the dashed line on the right would depend up the degree to which the protecting vegetation cover had been degraded. In effect, human destruction of the vegetation cover mimics drought destruction of the vegetation cover. One other factor, to which we alluded to earlier, would be the nature of the exposed sediment. If it were Pliocene marine clays which are highly susceptible to erosion, we could expect erosion to accelerate, and perhaps result in the catastrophic erosional events that occurred $\sim 40 \mathrm{ka}$, or such as those of the fall of 2013 and the winter of 2014. 
Figure 12. The Relationship between Sediment Yield Effective Precipitation (ppt), and Vegetation Cover is Plotted for a "Natural" Region, and with Potential Human Impact

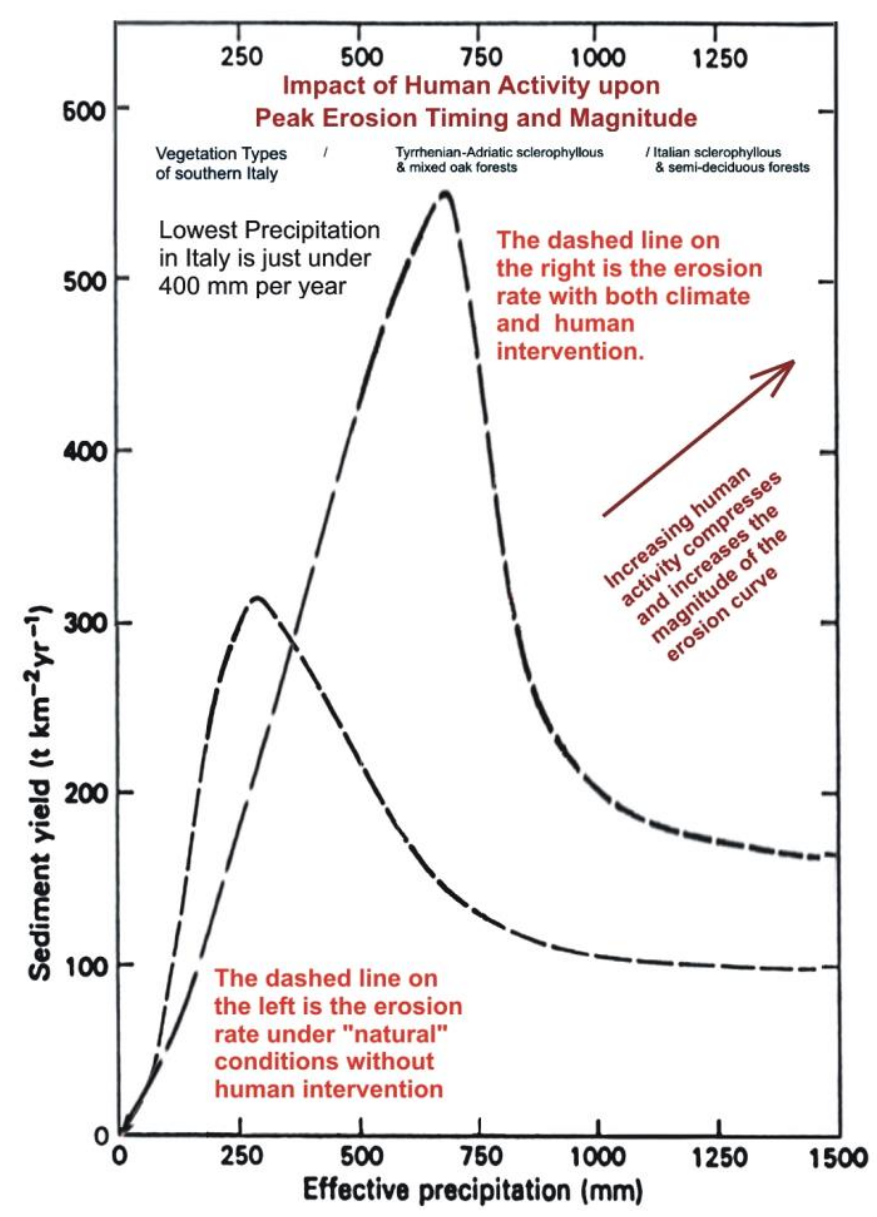

This model can be used to show the relationships between reconstructed precipitation, changes in vegetation cover, human activity, and the sequence of cut and fill events in the San Felice area during the Holocene. Although this diagram was originally devised as a synchronic plot of sites in one area at a single time, it can be used as a dynamic model to track changes in erosion rates on a landscape through time. All that is missing, as we have indicated above, is a more detailed knowledge the demography.

As we have indicated above there are several pollen records that can provide a record of climate variation during the Holocene. This is based upon variation in the abundance of forest species, which may, at times have been subject to clearance by human populations in the area. We suggest that the most sensitive indicator of Holocene climate change is the higher elevation pollen record at Lake Trifoglietti. The forest pollen abundance in the lower elevation sites were probably heavily impacted by human activity, and possibly earlier than we suspect. The spring discharge episodes provide a check on these records, but spring discharge is also susceptible to forest clearance. However, we can also utilize physical climate models that 
generate estimates of precipitation and temperature for thousands of years without using palaeoclimatic proxy data. One such model is the macrophysical climate model of Bryson (Bryson 1992). His model is basically a heat-budget model predicated upon orbital forcing, variations in atmospheric transparency, and the principles of synoptic climatology (Bryson and DeWall 2007). The model generates the climate at a specific site over a period of 39,000 years at 100 year intervals. The basic input data (average monthly precipitation, average monthly high temperature, average monthly low temperature, and monthly average temperature) are local weather station data for the period of record or thirty-year averages. However, other monthly average data can be entered into the model to generate many other climate data, e.g., snow fall, days below 0 degrees centigrade, number of rainy days, and so on. The closest long-term weather station to San Felice is at Gioia del Colle about $43 \mathrm{~km}$ to the east. Using the 30 -year weather data from the station there we have generated annual and seasonal climate data for the last 39,000 years.

The modeled annual precipitation (Figure 13) that we have generated can be compared with the record of climate reconstructed from the lake pollen records, alluvial erosion and deposition sequences, and spring discharge events, and even human activity might be extrapolated for the Holocene to determine if there are environmental events not accounted for in the climate record (Figure 13). We should be able to compare the affect of annual and seasonal temperature and precipitation for each season during the Holocene, and also be able to calculate effective precipitation. The longterm modeled annual precipitation is an excellent place to begin comparisons with the paleoenvironmental proxy data record (Figure 13).

Figure 13. Modeled Annual Precipitation for Gioia Del Colle for the Last 39,900 Years Using the Bryson MCM (Meso Scale Climate Model)

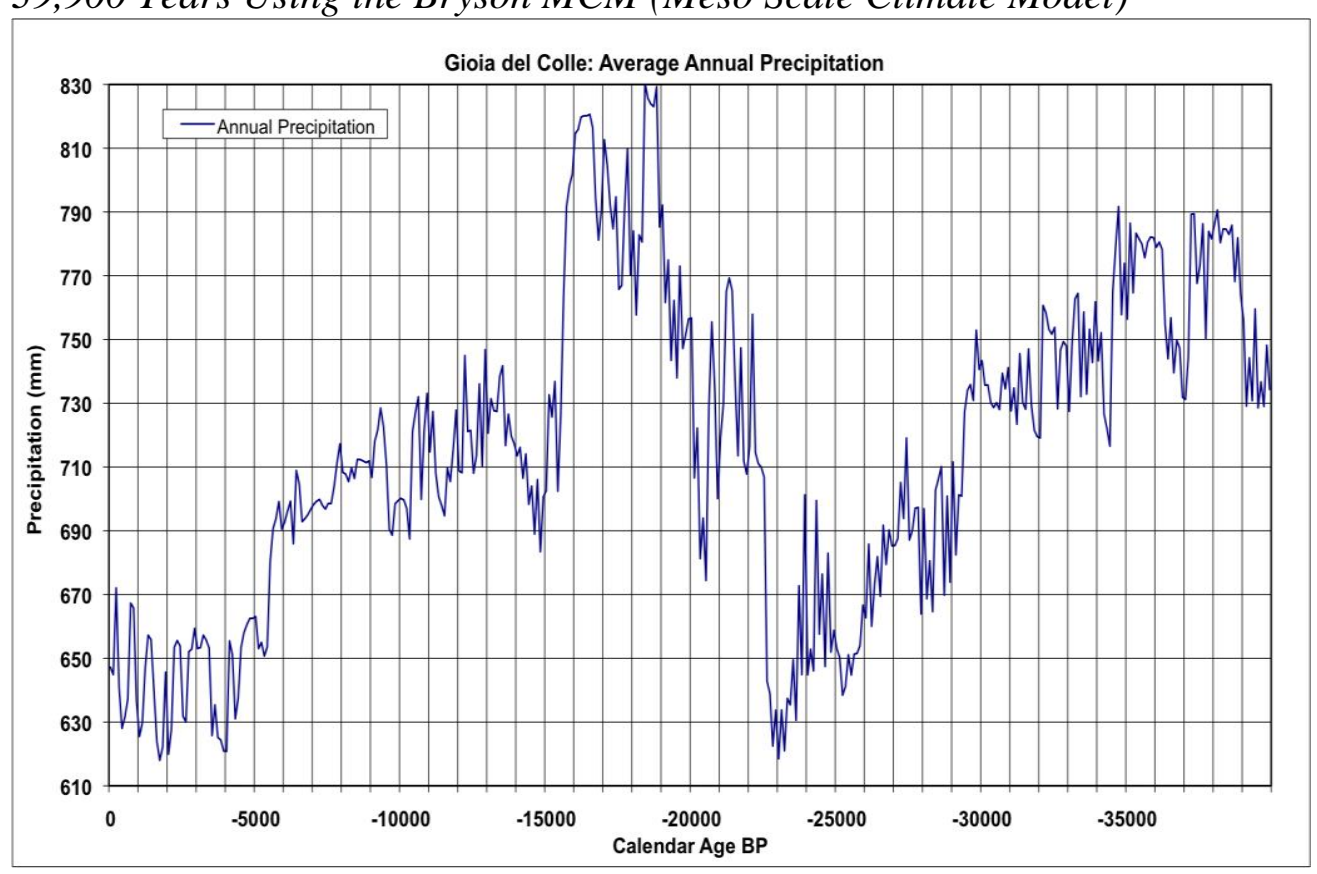


We can already use the climate model data for the last 12,500 years, calculate an effective precipitation with a standard conversion equation used by the U.S. Department of Agriculture:

\section{Effective Precipitation $=(($ PPT $)-5) X .75$}

Where PPT is the modeled precipitation in $\mathrm{mm}$. Five $\mathrm{mm}$ precipitation is the standard subtraction from the total precipitation that is then multiplied by .75 to obtain the effective precipitation. Then we can use the Langbein and Schumm model to predict a climate based erosion rate for the region on the border between Puglia and Basilicata (Figure 14).

Figure 14. Plot of Modeled-Calculate Effective Precipitation in Millimeters (Blue Line) Against the Predicted Sediment Yield in Metric Tons per Square Kilometer per Year (Red Line)

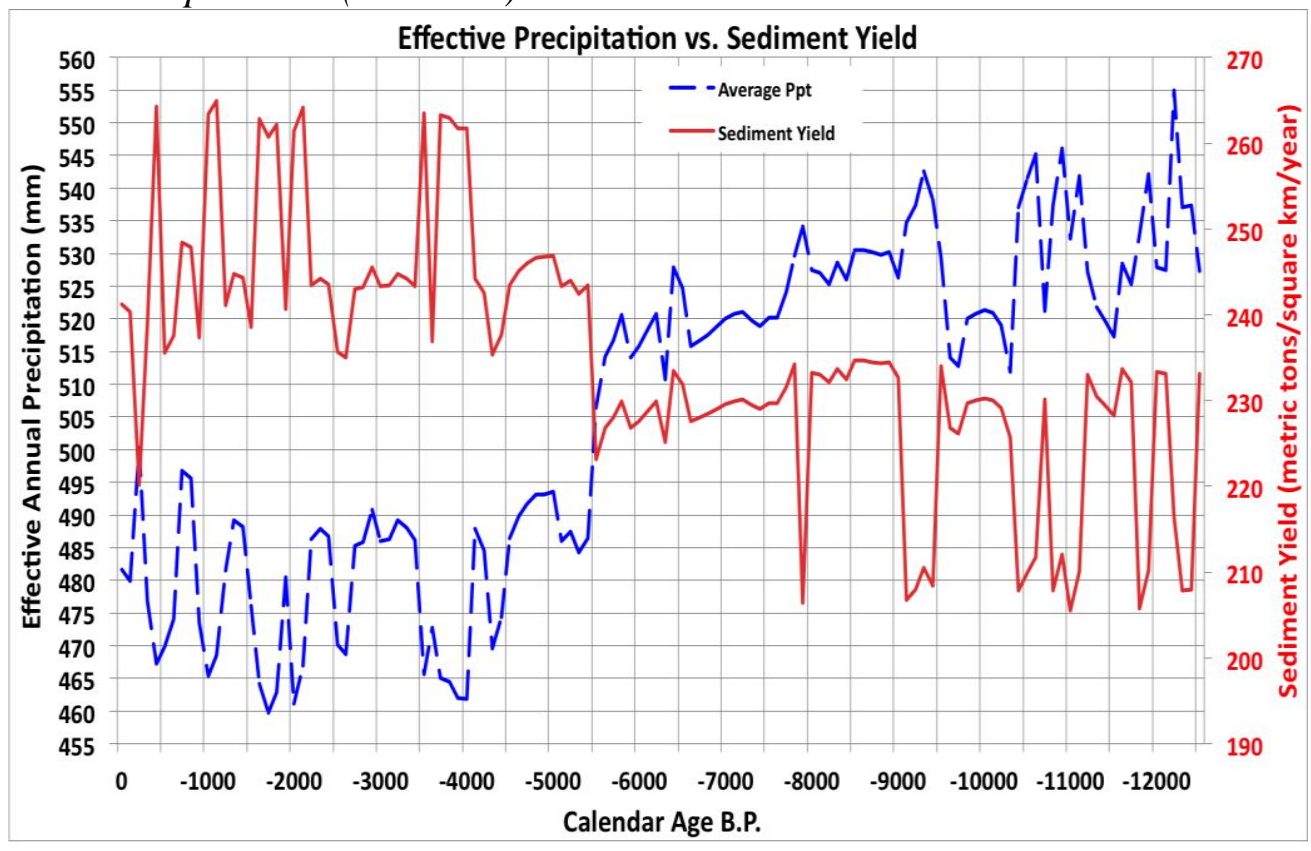

The correspondence between our model of erosion and the actual chronology of erosion compiled by Piccarreta et al. (2011) provides a test of our model (Figure 15). It is clear that decreased precipitation resulting in decreased vegetation cover results in increased erosion. The model indicates that highest Holocene erosion rates occur after 5,500 cal B.P. The data on erosion in southern Basilicata compiled by Piccarreta et al. (2011), except in one instance, shows the same pattern. In fact, most of the erosion cycles predicted by the model actually occur in Picarretta's record. The exceptions linked by blue lines in Figure 14 are not predicted by the climate model, but are significant episodes of erosion in the Picarretta et al. record. That suggests that these erosion cycles my not be climate based. The first of the two cycles of erosion not predicted by the climate based erosion model begins just after 7,500 cal B.P., but declines significantly after about 6,900 
cal B.P. though it continues to about $6,300 \mathrm{cal}$ B.P. The latter cycle begins about 3,500 cal B.P. and continues to just after 3,000 cal B.P. (Figure 15).

Figure 15. Plot of Modeled Erosion Cycles Using the Bryson and Bryson MCM Climate Model and the Langbein and Schumm Sediment Yield Model (Top) With the Summed Calibrated Radiocarbon Ages on Erosion Cycles in the Southern Basilicata Region

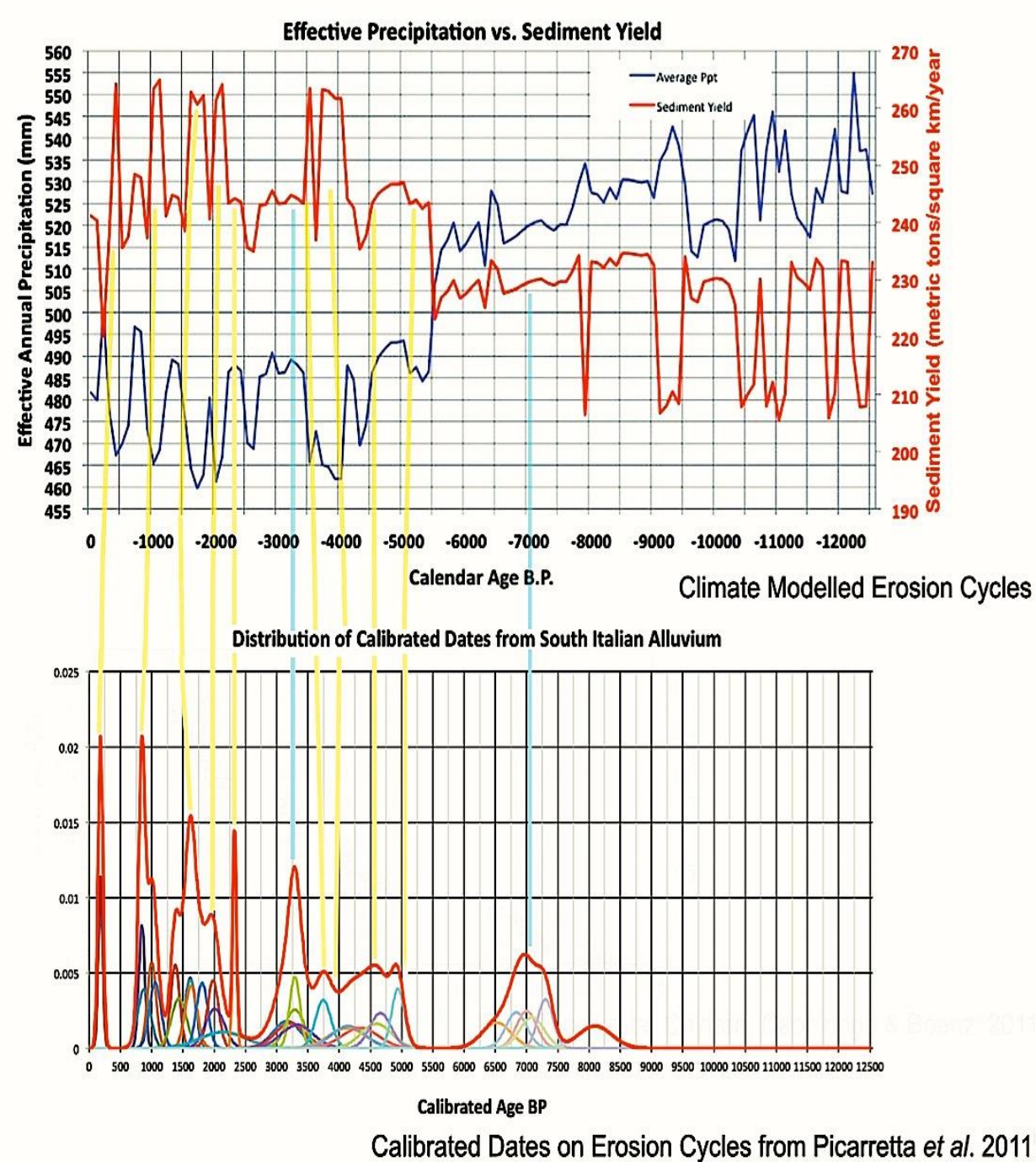

The Neolithic appears on the eastern and western coast of southern Italy just after 8,000 cal B.P. (Price 2000). This is just 300 to 400 years before we see significant erosion beginning in the interior of the region. We might suspect that there is a lag between coastal settlement and movement of farming peoples into the hinterlands. This would explain the delay in increased erosion rates for the interior that appear in the Picarretta et al. (2011) record, but not in the climate model. The scale of the erosion cycle documented by Picarretta suggests significant human impact upon the 
landscape, enough to mimic the results of a climate induced erosion cycle. The impact of these peoples continued for almost another 600 years!

The second erosion event that does not seem to be related to climate may be related to the late Bronze Age cultural activity in southern Italy. It predates the appearance of Indo European language speaking in southern Italy by about 600 to 700 years. It does however correspond to a series of intense droughts over a 150-year period from $1250 \mathrm{BC}$ to about $1100 \mathrm{BC}$ that led to severe cultural disruption in the eastern Mediterranean. This drought is recorded throughout the eastern Mediterranean in cultural records ranging from the Hittite Kingdom to New Kingdom Egypt. Our model seems to miss or underestimate this event, or it may be an event that was exacerbated by human land use. It is clear, however, that the erosion model based upon the MCM climate model and the Langbein and Schumm sediment yield model provides a good estimate of the timing and to some degree the scale of the erosion events expected.

Data on human activity is largely obtained from traditional archaeological excavation. However, large-scale archaeological surveys of areas in southern Italy are available and now being assembled that should reveal details regarding the demographics of southern Italy during the late Holocene. Surveys conducted by one of our authors (Dr. Myles McCallum) show Bronze and Iron Age settlement on hilltops, like Monte Serico and Monte Irsi, but also on high plateaus, like San Felice, Lamiecelle, and Oppido Lucano. Following the Bronze Age, some settlements remained on the higher elevations, but many people began to occupy sites in the valleys or on natural terraces on hillsides.

However, there are almost no sites located on valley bottom locations. This may in part reflect an avoidance of those areas due to disease. Some data suggest that episodes of hill-slope erosion correspond to sporadic damming of the channel of the Basentello River, and intermittent ponding. These would provide areas where mosquitoes could breed and malaria may have been common. These episodes probably occurred about 5,000, 2,000, and 400 years ago. However, a more likely explanation based upon our study is that valley floor sites are buried under two to three meters of sediment.

Some of the plateaus in the McCallum survey zone indicated long-term settlement, from the late Iron Age/Archaic Period through to Late Antiquity, and, in a couple of cases, into the early Middle Ages. Dr McCallum believes that his preliminary results will allow us to determine the location of human settlement in the region, at least from the early Iron Age to the Middle Ages (McCallum and Hyatt 2014).

These data suggest that, initially, more stable hilltop areas were impacted by agricultural peoples. These areas, usually composed of sands, or sandy silts on relatively level terrain, although impacted where not as sensitive to erosion as sites on the valley slopes or terraces. When people cleared these areas of native vegetation and began tilling or grazing, not only did they begin to move sediment down the steep slopes, but they also exposed the marine marls/clays to erosion. It is at that point in time when 
erosion may have accelerated more due to human activity rather than to climate. When this may have occurred is still a matter for conjecture, but the plots in Figure 15 suggest that erosion was much more extreme during the last 2,500 years than might be expected from drier climate alone.

Soil formation, seems to have occurred near the ends of periods of flooding and sediment deposition at a time when these processes may have been slowing or had ceased and ground surfaces were stable. This will have to be documented by more dates on the tops of soils where they have not been truncated. Additional dates on episodes of spring discharge should provide a more accurate indication of when ground water recharge occurred due to cooler, moister climates. This can then be compared to some of the records of lake levels in the region, such as the ones reported by Magny et al. (2007), Giraudi (2004), Giraudi (1998), and Primavera et al. (2011). Eventually we hope to be able to reconstruct the chronometric record of deposition and erosion events, episodes of soil formation, spring discharge cycles, and the dynamics of vegetation history in the San Felice region, and relate it to a more robust reconstruction of the climate record. Then, when we factor people into the equation, we will have a better idea of their role in landscape change in the landscape of the Mezzogiorno during the Holocene.

\section{Acknowledgements}

I thank Dr. M. McCallum for providing funding for our first Summer of travel to southern Italy, and for the radiocarbon dates, shipping some of the samples to the US, and payment of part of the sediment analyses provided by his Social Sciences and Humanities Research Council of Canada, Standard Research Grant \#410-2011-1201. We thank Dr. R. Negrini for allowing us use the Mastersizer in the Geology Department Laboratory at California State University, Bakersfield. Beyond this, all funding was our own.

Most importantly, I thank my students and colleagues without whom I could not have conducted this study. I also thank a young woman whose name, although not among the authors, was in Italy the summer of 2013. She helped us with so many things, but especially with her constant positive attitude despite some bad times. Her presence and support was and is greatly appreciated. I thank her for it.

\section{References}

Allen JRM, Brandt U, Brauer A, Hubberten H-W, Huntley B, Keller J, Kraml M, Mackensen A, Mingram J, Negendank JFW, Nowaczyk NR, Oberhansli H, Watts WA, Wulf S, Zolitschka B (1999) Rapid environmental changes in southern Europe during the last glacial period. Nature 400: 740-743.

Allen JRM, Watts WA, Huntley B (2000) Weichselian palynostratigraphy, palaeovegetation and palaeoenvironment; the record from Lago Grande di Monticchio, southern Italy. Quaternary International 73/74: 91-110. 
Allen JRM, Watts WA, McGee E, Huntley B (2002) Holocene environmental variability - the record from Lago Grande di Monticchio, Italy. Quaternary International 88: 69-80.

Allen JRM, Huntley B (2009) Last interglacial palaeovegetation, palaeoenvironments and chronology: A new record from Lago Grande di Monticchio, southern Italy. Quaternary Science Reviews 28(15-16): 1521-1538.

Blanco A, De Tomasi F, Filippo E, Manno D, Perrone MR, Serra A,. Tafuro AM, Tepore A (2003) Characterization of African dust over southern Italy. Atmospheric Chemistry and Physics 3: 2147-2159.

Boenzi F, Caldara M, Capolongo D, Dellino P, Piccarreta M, Simone O (2008) Late Pleistocene-Holocene landscape evolution in Fossa Bradanica, Basilicata (southern Italy). Geomorphology 102: 297-306.

Brauer A, Mingram J, Frank U, Gunter C, Schettler G, Wulf S, Zolitschka B, Negendank, JFW (2000) Abrupt environmental oscillations during the early Weichselian recorded at Lago Grande di Monticchio, southern Italy. Quaternary International 73/74: 79-90.

Brown GS (2003) The Norman conquest of Southern Italy and Sicily. Jefferson, North Carolina, McFarland.

Brückner H (1982) Ausmass von Erosion und Akkumulation im Verlauf des Quatär in der Basilicata (Süditalien) [Extent of erosion and accumulation in the course of the Quaternary in the Basilicata (Southern Italy)]. Zeitschrift für Geomorphologie. Supplementband 43:121-137.

Bryson, R. A. 1992. A macrophysical model of the Holocene intertropical convergence and jetstream positions and rainfall for the Saharan region. Meteorology and Atmospheric Physics 47(2):247-258.

Bryson RA, DeWall KM (2007) A paleoclimatology workbook: high resolution, sitespecific, macrophysical climate modeling. Mammoth Site of Hot Sprngs, SC Inc.

Campbell I, Bicket A, Sanderson DCW, Whitelaw L (2011) I Geomorphology. In Vagnari. Il villaggio, l'artigianato, la proprietà imperial, AS Small (Ed), 3751. Insulae Diomedeae 17. Bari: Edipuglia.

Carter JC (2006) Discovering the Greek countryside at Metaponto. Ann Arbor: University of Michigan.

Crawford FM (1905) Southern Italy and Sicily and the Rulers of the South. New York: The MacMillan Company.

Davies R (2013a) Floods in southern Italy 2013. Floodlist. Retrieved from http://bit.ly/ 2h5P3xz

Davies R (2013b) Floods in Puglia, Italy. Floodlist. Retrieved from http://bit.ly/ 2hgh7yD.

Di Rita F, Magri D (2009) Holocene drought, deforestation and evergreen vegetation development in the Central Mediterranean: a $5500 \mathrm{yr}$ record from Lago Alimini Piccolo, Apulia, Southeast Italy. Holocene 19: 295-306.

Edoardo ACC, L'Abate G, Barbetti R, Fantappié M, Lorenzetti R, Magini S (2012) Carta dei suoli d'Italia - Soil Map of Italy. Consiglio per ricerca e la sperimentazione in agricoltura, Ministero delle Politiche Agricole Alimentari e Forestali [Council for Research and Experimentation in Agriculture, Ministry of Agriculture, Food and Forestry]. Retrieved from http://bit.ly/2hl fxeB.

Favia P, Giuliani R, Small A, Small C (2005) La valle del Basentello e l'insediamento rurale di Vagnari in età tardoantica [The Basentello valley and the rural settlement of Vagnari in late antiquity]. In Paesaggi e insediamenti rurali in Italia meridionale fra tardoantico e altomedioevo, G Volpe, M Turchiano (Eds), 193-222. Bari: Edipuglia. 
Favia P, Giuliani R, Small AM, Small CM (2005) L'insediamento rurale di Vagnari e la valle del Basentello in età tardoantica [The rural settlement of Vagnari and Basentello valley in Late Antiquity]. In Paesaggi e insediamenti rurali in Italia meridionale fra Tardoantico e Altomedioevo, Atti del Io seminario sul Tardoantico e l'Altomedioevo in Italia Meridionale, Foggia 1214 febbraio 2004), G Volpe, M Turchiano (Eds), 193-222. Bari: Edipuglia.

Giraudi C (1998) Late Pleistocene and Holocene lake-level variations in Fucino Lake (Abruzzo, central Italy) inferred from geological, archaeological and historical data. In Palaeohydrology as Reflected in Lake-Level Changes as Climatic Evidence for Holocene Times: Paläoklimaforschung, vol. 25, SP Harrison, B Frenzel, U Huckried, M Weiss (Eds), 1-17.

Giraudi C (2004) Le oscillazioni di livello del Lago di Mezzano (Valentino-VT): variazioni climatiche e interventi antropici [The oscillations of the Mezzano lake level (Valentino-VT): climatic variations and human interventions]. Quaternario 17: 221-230.

Hearder H (1983) Italy in the age of the Risorgimento, 1790-1870. London: Longman.

Heinzel CE (2004) Greek, Phoenician, and Roman colonization v. Holocene landscape development: Environmental implications on a developing indigenous society, western Sicily. $\mathrm{PhD}$ dissertation, Northern Illinois University, DeKalb.

Heinzel C, Kolb M (2011) Holocene land use in western Sicily: a geoarchaeological perspective. Geological Society, London, Special Publications, v. 352, 97-107.

Horsnaes HW (2002) The cultural development in north western Lucania c. 600273 BC. Romae, "L'Erma" di Bretschneider.

Huntley BM, Allen JRM, Watts WA, Zolitschka B (1999) Palaeoclimate, chronology and vegetation history of the Weichselian Lateglacial: comparative analyses of data from three cores at Lago Grande di Monticchio, southern Italy. Quaternary Science Reviews 18: 945-960.

Joannin S, Brugiapaglia E, de Beaulieu J -L, Bernardo L, Magny M, Peyron O, Vanniere B (2012) Pollen-based Reconstruction of Holocene Vegetation and Climate in Southern Italy: the Case of Lago di Trifoglietti. Climate of the Past Discussions 8: 2223-2279.

Langbein WB, Schumm SA (1958) Yield of sediment in relation to mean annual precipitation. Transactions, American Geophysical Union 39(6): 1076-1084.

Magny M, de Beaulieu J-L, Drescher-Schneider R, Vanniere B, Walter-Simonnet A-V, Miras Y, Millet L, Bossuet G, Peyron O, Brugiapaglia E, Leroux A (2007) Holocene climate changes in the central Mediterranean as recorded by lake-level fluctuations at Lake Accesa (Tuscany, Italy). Quaternary Science Reviews 26: 1736-1758.

McCallum M, vanderLeest J, Veal R, Taylor A, Brown L, Cooney W, Munro M (2011) A preliminary report on field work at San Felice. 2004- 2010 Mouseion, Series 3, 11.2: 25-108. Bari, Italy.

McCallum M, Hyatt A (2014) A View of Vagnari from across the Basentello: Initial Results from the BVARP Survey, 2012. In Atti, Beyond Vagnari Conference, University of Edinburgh, October 26 - 28, 2012, A. Small, (ed), 169-180. Bari: Edipuglia.

McCallum M, vanderLeest J (2014) Research at San Felice: the villa on the imperial estate. In Atti, Beyond Vagnari Conference, University of Edinburgh, October 26 - 28, 2012, A Small (Ed), 123 - 134. Bari: Edipuglia.

McCallum (2015) Excavations at Vagnari. Retrieved from http://bit.ly/2g9NFFu.

Musca G (1964) L'Emirato di Bari 847-871 [L'Emirato di Bari 847-871]. Bari: Dedale Litostampa. 
Piccarreta M, Caldara M, Capolongo D, Boenzi F (2011) Holocene geomorphic activity related to climatic change and human impact in Basilicata, Southern Italy. Geomorphology 128(2011): 137-147.

Pieri P, Rechichi PD, Azzaroli A, Perno U, Geronzi A, Gioria C (1968) Carta Geologica d'Italia alla scala 1:100,000 [Geological map of Italy at the scale 1: 100,000] . Foglio 188, Gravina in Puglia. Italy: Servizio Geologico.

Price TD (2000) Europe's first farmers. Cambridge University Press.

Primavera M, Simone O, Fiorentino G, Caldara M (2011) The palaeoenvironmental study of the Alimini Piccolo Lake enables a reconstruction of Holocene sealevel changes in south-east Italy. The Holocene 21(4): 553-563.

Sadori L, Narcisi B (2001) The Postglacial record of environmental history from Lago di Pergusa, Sicily. The Holocene 11(6): 655-670.

Sadori L, Giardini M (2007) Charcoal analysis, a method to study vegetation and climate of the Holocene: the case of Lago di Pergusa, Sicily (Italy). Geobios 40(2): 173-180.

Sadori L, Zanchetta G, Giardini M (2008) Last Glacial to Holocene palaeoenvironmental evolution at Lago di Pergusa (Sicily, Southern Italy) as inferred by pollen, microcharcoal, and stable isotopes. Quaternary International 181: 4-14.

Small AM (2003) New evidence from tile stamps for imperial properties near Gravina, and the topography of imperial estates in South East Italy. Journal of Roman Archaeology 16(2003): 301-321.

Small CM, Small AM (2005) Defining an imperial estate: the environs of Vagnari in South Italy. In Communities and Settlements from the Neolithic to the Early Medieval Period, Volume II, P Attema, A Nijboer, A Zifferero (Eds), 894902. Proceedings of the 6th Conference of Italian Archaeology, University of Groningen April 15-17, 2003. Oxford, BAR.

Small AM (2006) The Production and distribution of bricks and tiles in South Italy: the evidence of Vagnari. In Noctes Campanae. Studi di storia antica ed archeologia preromana e romana in memoria di Martin W. Frederiksen, WV Harris, E Lo Cascio (Eds), 191-211. Naples: Luciano.

Small AM, Small CM (Eds) (2007) Excavation in the Roman cemetery at Vagnari in the territory of Gravina in Puglia 2002. With contributions by Alessandra De Stefano, Roberta Giuliani, Martin Henig, Kathryn Johnson, Philip Kenrick, Tracy Prowse, Alastair Small and Hans vanderLeest, 123-229. Papers of the British School at Rome.

Small AM (2011) Vagnari: il villaggio, l'artigianato, la proprietà imperial [Vagnari: The village, the industries, the imperial property], 126-129. Bari: Edipuglia.

Summa V, Giannossi ML (2013) Chapter 1: The Role of Soil Mineralogy, Geochemistry and Grain Size in the development of Mediterranean Badlands: A Review. In Soil Processes and Current Trends in Quality Assessment, MC Hernandez Soriano (Ed), 3-32. InTech.

Vezzani L, Festa A, Ghisetti FC (2010) Geology and Tectonic Evolution of the Central-Southern Apennines, Italy. The Geological Society of America, Special Paper 469.

Watts WA, Allen JRM, Huntley B (1996a) Vegetation history and palaeoclimate of the last glacial period at Lago Grande di Monticchio, Southern Italy. Quaternary Science Reviews 15: 133-154.

Watts WA, Allen JRM, Huntley B, Fritz SC (1996b) Vegetation history and climate of the last 15,000 years at Laghi di Monticchio, Southern Italy. Quaternary Science Reviews 15: 113-132. 
Weiss H (1982) The decline of Late Bronze Age civilization as a possible response to climatic change. Climatic Change 4(2): 173-198.

Wilson L (1973) Variations in mean annual sediment yield as a function of mean annual precipitation. American Journal of Science 273: 335-349. 